\title{
WORKING
}

paper

\section{Countercyclical School Attainment and Intergenerational Mobility}

\section{Andreu Arenas $^{1} \&$ Clément Malgouyres $^{2}$}

\author{
May 2018, WP \#679
}

\begin{abstract}
We study how economic conditions at the time of choosing post-compulsory education affect intergenerational mobility. Exploiting local variation in birthplace unemployment rate at age 16 across 23 cohorts in France, we find that cohorts deciding on post-compulsory education in bad economic times are more educationally intergenerationally mobile - their level of educational attainment is less related to having a white-collar father. These cohorts are also more occupationally intergenerationally mobile; and a large fraction of this effect is explained by business cycle-induced differences in educational attainment. Results are robust to accounting for differential spatial mobility between birth and age 16 by parental occupation. Finally, we provide additional evidence that high local unemployment at age 16 increases the relative school enrollment rate of children of blue collar workers the year after - at age $17 .{ }^{3}$
\end{abstract}

Keywords: Intergenerational mobility, business cycle, human capital, occupational choice.

JEL classification: J24, I21, E24.

\footnotetext{
${ }^{1}$ CORE, Université catholique de Louvain. Email: andreu.arenasjal@,uclouvain.be.

${ }^{2}$ Institut des politiques publiques, clement.malgouyres@ipp.eu.

3 We are grateful to the editor, two anonymous referees, Philippe Aghion, Samuel Bentolila, Pierre Cahuc, Bart Cockx, Juan Dolado, Bertrand Garbinti, Laura Hospido, Jean Hindriks, Andrea Ichino, Fabian Lange, Franc ois $_{s}$ Maniquet, Dominik Sachs, Milena Suarez, Bruno Van der Linden and conference and seminar participants for helpful comments. We also thank INSEE and the Centre Maurice Halbwachs $(\mathrm{CMH})$ for giving us access to the data and for their help. The data used in this paper can be accessed through the CMH. This research was mostly carried out when Clément Malgouyres was working at the Banque de France. The views expressed here are those of the authors only and do not necessarily reflect the views of the Banque de France or the Eurosystem.
}

Working Papers reflect the opinions of the authors and do not necessarily express the views of the Banque de France. This document is available on publications.banque-france.fr/en 


\section{NON-TECHNICAL SUMMARY}

Educational choices are endogenous to aggregate economic conditions. Whenever it is more difficult to find a job, the earnings foregone while at school decrease. At the same time, without those earnings, or with reduced parental earnings, it might be more difficult to finance post-compulsory education. Existing evidence shows that, on average, education tend to be counter-cyclical, meaning that changes in opportunity costs dominate ability to pay considerations, with cohorts exposed to adverse economic conditions in critical ages obtaining significantly more schooling. However, it is not obvious how the fluctuations in schooling across cohorts induced by the business cycle will be related to parental occupation. Credit constraints are larger for low-skill families, but the change in the optimal level of schooling induced by changes in opportunity costs might be larger for children of these families. In addition, the number of students at the margin where economic conditions change the optimal level of schooling might also differ by parental occupation.

The empirical question we address in this paper is whether the link between parental and educational attainment significantly differs across cohorts exposed to different conditions when deciding to pursue post-compulsory schooling; and if it does, whether this translates into long-lasting differences in the relationship between parental occupation and labor market performance.

This is an important question for a better understanding of the determinants of intergenerational mobility (IGM) in income within a society, since skill acquisition is one of the main channels for the transmission of economic advantage across generations (Solon, 1999). Moreover, it provides new insights on the longrun effects of exposure to business cycle fluctuations at critical ages.

We address this question using a large sample of labor force survey data on 23 cohorts across 96 French provinces (départements), exploiting variation in the unemployment rate in the individuals' province of birth at age 16, and information on labor market outcomes, educational attainment, and parental occupation. Crucial in our empirical exercise is the use of local-level variation in economic conditions, allowing us to net out time-specific unobserved heterogeneity, including national trends and policies; the use of the unemployment rate by province of birth, allowing us to rule out geographical sorting due to economic conditions at the moment of choosing education; and the use of the unemployment rate at the moment of finishing post-compulsory education, allowing us to rule out simultaneity problems between the unemployment rate and the cohort's education decisions. Our measures of schooling attainment are indicators for holding post-compulsory and college degrees. Our measure of labor market outcomes, both for the children and the parents, is binary - white vs. blue collar occupation -, and is strongly correlated with contemporaneous earnings and educational attainment, which we do not observe for parents.

We find that cohorts deciding on post-compulsory education in bad economic times are more educationally intergenerationally mobile, meaning that their educational attainment is less correlated with having a white-collar father. We find an analogous effect in the labor market: these cohorts are also more occupationally intergenerationally mobile, meaning that their probability of obtaining a white-collar job is less correlated with having a white-collar father.

We frame our analysis and interpret the findings using a one-factor model of selection into education where education affects the probability of access to white versus blue-collar occupations and withinoccupation earnings. The model allows us the decompose the business cycle implications of occupational IGM into a component that is driven by the endogenous responses of educational attainment and a component that reflects changes in occupational IGM due to changes in the occupational returns of education. We find that the former component appear much more potent.

Our results suggest that although recessions might tend to increase inequality (Bonhomme and Hospido, 2017), due for instance to the skill-biased nature of unemployment, the lack of labor market alternatives pushes especially the children of the low skilled to obtain more education, resulting in higher IGM in education and labor market outcomes within the treated cohorts.

Since we exploit variation based on the unemployment rate at the province of birth, one possible concern is about differential spatial mobility between birth and age 16 (and hence exposure to economic conditions) by parental occupation. We account for this possibility by using a Two-Sample 2SLS estimator, finding that it is unlikely to explain our findings, and if anything, it reinforces the results.

Finally, we provide evidence that gap between white and blue-collar children in terms of enrollment is negatively affected by the unemployment rate faced at age 16, but that this effect changes in sign at age 23 - i.e. the enrollment decisions of children of white collar workers are relatively more countercyclical with respect to unemployment faced at age 23. These results, displayed in Figure 1, are quite intuitive as they 
suggest that individuals with blue-collar parents adjust relatively more through enrollment in postcompulsory secondary education while children of white-collars use higher education as a buffer against local economic conditions relatively more.

\section{Impact of local unemployment on school enrollment differential between children of white and blue collar families, for different age of exposure}

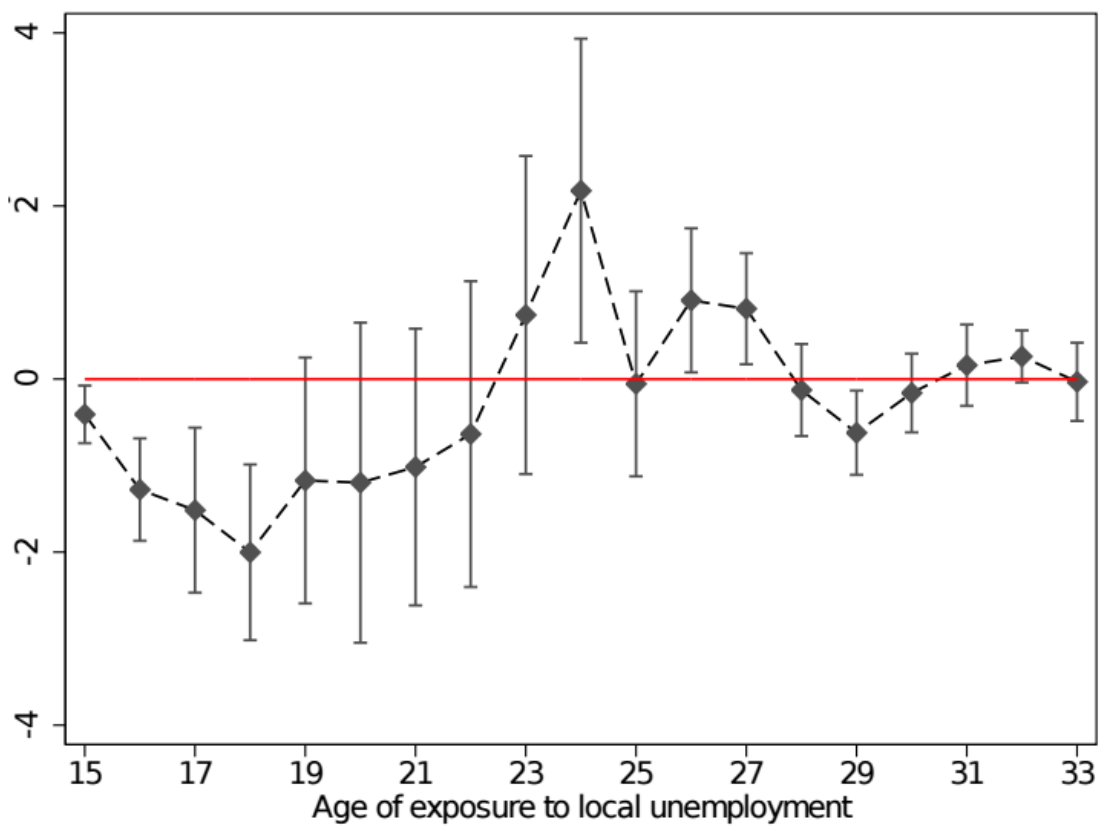

Note: This figure represents the differential effect of the local business cycle on schooling enrollment between individuals with white- versus blue-collar parents for a different age of exposure to the shock (x-axis). At age 16, a 1 pp rise in local unemployment decreases the gap in enrollment at age 17 between children of white and blue collar families by about one $1 \mathrm{pp}$. This effect remains negative for shocks experienced between age 15 and 20. It reverses in sign around age 23 and 24, suggesting children of white collar families adjust relatively more to the business cycle through higher education while children of blue collar do so relatively more through post-compulsory secondary education. Source: French LFS, authors calculations - 1982-2016.

\section{Réussite scolaire contra-cyclique et mobilité intergénérationnelle}

Nous étudions comment les conditions économiques au moment de choisir son éducation postobligatoire affectent la mobilité intergénérationnelle. Nous exploitons la variation locale du taux de chômage à l'âge de 16 ans pour 23 cohortes en France. Nous constatons que les cohortes qui décident d'une éducation post-obligatoire en période économique difficile sont plus mobiles d'une génération à l'autre d'un point de vue éducationnel - leur niveau d'éducation est moins lié au fait d'avoir un père qui occupe une occupation de col blanc (cadre ou profession intermédiaire). Ces cohortes sont également plus mobiles d'une génération à l'autre sur le plan professionnel; et une grande partie de cet effet s'explique par les différences de niveau de scolarité induites par le cycle économique. Les résultats sont robustes si l'on tient compte de la mobilité spatiale différentielle entre la naissance et l'âge de 16 ans selon la profession parentale.

Mots-clés : mobilité intergénérationnelle, cycle économique, capital humain, capital humain, choix professionnel

Les Documents de travail reflètent les idées personnelles de leurs auteurs et n'expriment pas nécessairement la position de la Banque de France. Ce document est disponible sur publications.banque-france.fr 


\section{Introduction}

Educational choices are endogenous to aggregate economic conditions. Whenever it is more difficult to find a job, the earnings foregone while at school decrease. At the same time, without those earnings, or with reduced parental earnings, it might be more difficult to finance postcompulsory education. Existing evidence for the US, France, and Mexico (Dellas and Sakellaris, 2003; Gaini et al., 2013; Charles et al., 2015; Atkin, 2016) shows that, on average, education is counter-cyclical, meaning that changes in opportunity costs dominate ability to pay considerations, with cohorts exposed to adverse economic conditions in critical ages obtaining significantly more schooling. However, it is not obvious how the fluctuations in schooling across cohorts induced by the business cycle will be drawn from the parental income distribution. Credit constraints are larger for low-income families, but the change in the optimal level of schooling induced by changes in opportunity costs might be larger for children of low-income families. For instance, this could be due to differences in returns to education by parental occupation, possibly because of complementarities with earlier investments (Cunha and Heckman, 2008; Cunha et al., 2010); or to differences in discount rates (Tanaka et al., 2010; Banerjee and Mullainathan, 2010). In addition, the number of students at the margin where economic conditions change the optimal level of schooling might also differ by parental occupation. ${ }^{1}$

The empirical question we address in this paper is whether the parental occupation gradient in education significantly differs across cohorts exposed to different conditions at the moment of deciding on schooling; and if it does, whether it translates into long-lasting differences in the parental occupation gradient in labor market performance. This is an important question for a better understanding of the determinants of intergenerational mobility (IGM) in income within a society, since skill acquisition is one of the main channels for the transmission of economic advantage across generations (Solon, 1999). Moreover, it provides new insights on the long-run effects of exposure to business cycle fluctuations at critical ages. We address this question using a large sample of labor force survey data on 23 cohorts across 96 French provinces (départements), exploiting variation in the unemployment rate in the individuals' province of birth at age 16, and information on labor market outcomes, educational attainment, and parental occupation. Crucial in our empirical exercise is the use of local-level variation in economic conditions, allowing us to net out time-specific unobserved heterogeneity, including national trends and policies; the use of the unemployment rate by province of birth, allowing us to rule out geographical sorting due

\footnotetext{
${ }^{1}$ Children of rich/white collar parents are more likely to be always takers. Findeisen and Sachs (2016) show how the number of students at the margin is a crucial parameter for the effects of financial aid on college enrollment.
} 
to economic conditions at the moment of choosing education; and the use of the unemployment rate at the moment of finishing post-compulsory education, allowing us to rule out simultaneity problems between the unemployment rate and the cohort's education decisions. ${ }^{2}$ Our measures of schooling attainment are indicators for holding post-compulsory and college degrees. Our measure of labor market outcomes, both for the children and the parents, is binary - white vs. blue collar occupation -, and is strongly correlated with contemporaneous earnings and educational attainment, which we do not observe for parents.

The results indicate that cohorts deciding on post-compulsory education in bad economic times are more educationally intergenerationally mobile, meaning that their educational attainment is less correlated with having a white-collar father. We find an analogous effect in the labor market: these cohorts are also more occupationally intergenerationally mobile, meaning that their probability of obtaining a white-collar job is less correlated with having a white-collar father. We find that a large fraction of this difference in occupational IGM is explained by differences in educational attainment, which is consistent with our first finding. Hence, our results suggest that although recessions might tend to increase inequality (Bonhomme and Hospido, 2017), due for instance to the skill-biased nature of unemployment, the lack of labor market alternatives pushes especially the children of the low skilled to obtain more education, resulting in higher IGM in education and labor market outcomes within the treated cohorts. The results are robust across a number of specifications, the most demanding one featuring province by year of birth fixed effects, that absorb all unobserved heterogeneity within a cohort in a province, province by parental occupation fixed effects, that absorb all time-invariant unobserved differences between white and blue collar workers that might systematically change across provinces, and province by parental occupation time trends. Occupational IGM regressions feature additional controls - survey year by birth year fixed effects and age at survey by parental occupation fixed effects -, to allow for heterogeneous career profiles by age and parental occupation (Lee and Solon, 2009). We frame our analysis and interpret the findings using a one-factor model of selection into education where education affects the probability of access to white versus blue-collar occupations and within-occupation earnings. The model allows us the decompose the business cycle implications of occupational IGM into a component that is driven by the endogenous responses of educational attainment and a component that reflects changes in occupational IGM due to changes in the occupational returns of education.

\footnotetext{
${ }^{2}$ The literature using aggregate unemployment rates is indeed subject to the criticism that national unemployment rate might be correlated with nation-wide reforms. This issue is particularly salient in the French case during the period analyzed, as many of the late 1980s reform to increase educational attainment were decided partly as a reaction of the high unemployment rate among the youth which was in part cyclical (Gaini et al., 2013; Esquieu and PouletCoulibando, 2003).
} 
The latter component could potentially be biased for students with low parental occupation, notably if parental networks are more intensively used during periods of high unemployment rates, as shown in Kramarz and Skans (2014), and that white collar parents' networks are more productive. The empirical results presented in the paper show that the former effect is a much more potent force explaining the counter-cyclicality of occupational IGM and that the latter effect is not significantly different from zero.

Since we exploit variation based on the unemployment rate at the province of birth, one possible concern is about differential spatial mobility between birth and age 16 (and hence exposure to economic conditions) by parental occupation. It could be for instance that high parental occupation students are found to be relatively less responsive to their birthplace's economic conditions simply because they are more likely to have moved and be exposed to different economic conditions at age 16. We account for this possibility by using a Two-Sample 2SLS estimator (Angrist and Krueger, 1992; Inoue and Solon, 2010), finding that it is unlikely to explain our findings, and if anything, it reinforces the results.

Finally, to complement our previous results on educational attainment and labor market outcomes, that use retrospective information on adults older than 26 , we use data on current school enrollment of young adults (age 16) in the Labor Force Survey. We provide evidence that students with blue collar parents react more strongly to the unemployment rate faced at age 16 than students with white collar parents, but that this gap reverses and changes sign at age 23 - i.e. the enrollment decisions of children of white collar workers are relatively more countercyclical with respect to unemployment faced at age 23. These results are quite intuitive as they suggest that individuals with blue-collar parents adjust relatively more through enrollment in post-compulsory secondary education while children of white-collars use higher education as a buffer against local economic conditions relatively more.

By identifying a channel through which the transmission of economic advantage fluctuates across cohorts, we contribute to the literature on the determinants of inter-generational mobility within countries - an exercise that is very data demanding (our sample features almost 200.000 adults with retrospective information, more than 20 cohorts across 96 local labour markets). Recent papers have empirically examined the geography of inter-generational mobility (Chetty et al., 2014); its evolution over time (Aaronson and Mazumder, 2008; Lee and Solon, 2009; Güell et al., 2014; Olivetti and Paserman, 2015; Barone and Mocetti, 2016); the role of women's rising labor force participation (Hellerstein and Morrill, 2011); the role of the education system (Oreopoulos and Page, 2006; Pekkarinen et al., 2009); the effect of worker displacement (Oreopoulos et al., 
2008); and the correlation of mobility measures with economic and social outcomes (Güell et al., 2015). ${ }^{3}$ Our results imply that a cohort exposed to worse economic conditions at age 16 (for instance, to the 75 th percentile of the unemployment rate as opposed to 25 th percentile) features an intergenerational elasticity of being employed in a white collar occupation that is $4 \%$ lower. This effect is economically significant, but relatively small compared to the effect of a change in the educational system. For instance, Pekkarinen et al. (2009) report a 23\% reduction in the intergenerational elasticity of income in Finland after a major educational reform that shifted the selection of students to vocational and academic tracks from age 11 to age 16.

Our findings complement an increasing body of evidence highlighting that adverse economic shocks at early stages of individuals' lives can have persistent effects on labor market outcomes, health, fertility, or preferences (e.g. Maclean, 2013; Giuliano and Spilimbergo, 2014; Chabé-Ferret and Gobbi, 2016). Most relevant to us are the well documented wage losses entailed by entering the labor market in a recession (Arulampalam, 2001; Oreopoulos et al., 2012; Altonji et al., 2016; Cockx and Ghirelli, 2016). In this paper, we add to this literature by studying how the exposure to adverse economic conditions at the moment of making educational choices attenuates the role of parental occupation for students' education and labor market outcomes, through its effects on the opportunity costs of schooling, despite its effect on the ability to pay for it. The lack of economic opportunities makes early school leaving less attractive, and prevents a significant fraction of children of low-skilled families from doing it, which makes them more likely to obtain additional qualifications and eventually a white collar job.

Our paper is also closely related to existing contributions analysing the effects of the business cycle on education (Betts and McFarland, 1995; Dellas and Sakellaris, 2003; Black et al., 2005; Méndez and Sepúlveda, 2012; Gaini et al., 2013; Charles et al., 2015; Aparicio-Fenoll, 2016; Atkin, 2016; Maier and Vujić, 2017). The main contribution of our paper is that it focuses on differences by parental occupation and on long-run outcomes in the labor market, while these analyzes are generally restricted to enrollment or more rarely educational attainment. The closest papers to ours are Gaini et al. (2013), that study school-leaving decisions in France as a function of the national business cycle, finding that they are mostly driven by students of lower socioeconomic status; and Charles et al. (2015) and Atkin (2016), which exploit the US housing boom and Mexico's trade reforms, respectively, to show that good economic conditions at the local level reduce college enrollment and the probability of school drop-out, respectively. In our paper, we

\footnotetext{
${ }^{3} \mathrm{~A}$ large number of papers examine determinants of cross-country differences in intergenerational mobility, see Black and Devereux (2011) and Corak (2013) for a literature review.
} 
exploit local variation, and link it further to labor market outcomes, focusing on the heterogeneity of the effects by parental occupation and its implications in terms of (occupational) IGM.

The rest of the paper is organized as follows. Section 2 develops a static Roy model where parental-occupation-specific returns to education and educational choices combine to determine the intergenerational persistency of occupational status. In Section 3.2, we present the data and descriptive statistics on educational and occupational IGM. Section 4 presents the empirical specification. Main results are presented in Section 5, while channels and robustness checks are presented in Section 6. Section 7 concludes.

\section{Conceptual Framework}

\subsection{Setup: Roy Model}

We develop a simple Roy Model of selection into education in an economy with two types of occupations (white and blue collar jobs). Suppose that individuals are distinguished by an unobserved ability type $z \sim N\left(\mu, \sigma^{2}\right)$, and that the returns to ability in the labor market depend on education and the occupation in which the individual will be employed - a blue or a white collar occupation. While education will affect wages within a given occupation as well as the probability of accessing a given occupation, unobserved ability $z$ is restricted to solely affect the within-occupation component of wages. In other words, there is random allocation to occupation within an educational group. ${ }^{4}$ Assuming log-utility, the expected utility from labor income depending on education $\left(W_{0}(z)\right.$ for low education, $W_{1}(z)$ for high education) can be written as:

$$
\begin{aligned}
& W_{0}(z)=p_{0}^{w c} W_{0}^{w c}(z)+\left(1-p_{0}^{w c}\right) W_{0}^{b c}(z) \\
& W_{1}(z)=p_{1}^{w c} W_{1}^{w c}(z)+\left(1-p_{1}^{w c}\right) W_{1}^{b c}(z)
\end{aligned}
$$

where $p_{i}^{h}$ refers to the probability of obtaining occupation $h \in\{w c, b c\}$ (white collar, blue collar) conditional on having educational level $i=0,1$ (low, high). $W_{i}^{h}$ refers to log-earnings from having job $h$ conditional on education $i$. The wage earned for education level $i$, occupation $h$ and unobserved ability $z$ is given by a $\log$-linear specification in $z$ :

$$
W_{i}^{h}(z)=\alpha_{i}^{h}+\beta_{i}^{h} z \text { where } i=0,1 \text { and } h=b c, w c
$$

\footnotetext{
${ }^{4}$ This captures a setting where at the moment of hiring, only educational credentials are observable, and individual ability only becomes observable and can be rewarded once in the job.
} 
For both blue and white collar occupations, we assume that $\alpha_{1}^{h}>\alpha_{0}^{h}>0$, meaning that education has an unconditional positive effect on earnings; and that $\beta_{1}^{h}>\beta_{0}^{h}>0$, meaning that education and ability are complements, which will then imply that high-ability individuals are positively selected into education. The expected log-income for education level $i$ is given by :

$$
W_{i}=\underbrace{\left(p_{i}^{w c} \alpha_{i}^{w c}+\left(1-p_{i}^{w c}\right) \alpha_{i}^{b c}\right)}_{\equiv \alpha_{i}}+\underbrace{\left(p_{i}^{w c} \beta_{i}^{w c}+\left(1-p_{i}^{w c}\right) \beta_{i}^{b c}\right)}_{\equiv \beta_{i}} \times z
$$

Given a cost of education $c$, individuals obtain education if:

$$
W_{1}-c \geq W_{0} \Leftrightarrow z \geq \frac{\alpha_{0}-\alpha_{1}+c}{\beta_{1}-\beta_{0}} \equiv z^{*}
$$

Hence, all individuals of type $z \geq z^{*}$ obtain education, where:

$$
z^{*} \equiv \frac{\alpha_{0}-\alpha_{1}+c}{\beta_{1}-\beta_{0}}=\frac{c}{\beta_{1}-\beta_{0}}-\eta
$$

Where in turn, $\eta=\frac{\alpha_{1}-\alpha_{0}}{\beta_{1}-\beta_{0}}$ is the ratio of ability-unrelated over ability-related returns to schooling. Intuitively, if the returns to education are mostly independent of ability, the ability threshold will be lower; while if the complementarities between ability and education are high, the ability threshold will be higher. The ability threshold increases with the costs of schooling, weighted by the ability-related returns to education: the increase is higher whenever the ability-related returns to educated are lower. Since $z$ is normally distributed $-z \sim N\left(\mu, \sigma^{2}\right)$, we can write the probability of obtaining education $i=1$ as:

$$
P\left(z>z^{*}\right)=\Phi\left(\frac{\mu-z^{*}}{\sigma}\right) \equiv H\left(z^{*}\right)
$$

The aim of this paper is to answer two empirical questions: the effect of the business cycle on educational IGM and the effect of the business cycle on occupational IGM. To this aim, we allow parental occupation to affect the distribution from which ability is drawn, the returns to education function, and the probability of occupying a white-collar job conditional on education. 


\subsection{The educational intergenerational mobility implications of the business cycle}

Empirically, we will model the probability of obtaining a post-compulsory degree with a linear probability model. We denote by $P(i=1 \mid b)$ the probability of obtaining a post-compulsory degree conditional on parental occupation $b$, which is either high $(H)$ or low $(L)$, meaning that her father occupies a blue collar and white collar job, respectively. Denoting by $\mathbf{1}()$ the indicator function and by $u$ the (local) unemployment rate:

$$
P(i=1 \mid b, u)=\mu+\delta_{0} \cdot u+\delta_{1} \cdot \mathbf{1}(b=H)+\delta_{2} \cdot u \times \mathbf{1}(b=H)
$$

We are interested in estimating $\delta_{2}$ :

$$
\delta_{2}=\frac{\partial P(i=1 \mid H)}{\partial u}-\frac{\partial P(i=1 \mid L)}{\partial u}=H^{\prime}\left(z_{H}^{*}\right) \frac{\partial z_{H}^{*}}{\partial u}-H^{\prime}\left(z_{L}^{*}\right) \frac{\partial z_{L}^{*}}{\partial u}
$$

Note that differential responses of educational attainment could arise for two reasons. First, due to differences in how the ability threshold $z^{*} \equiv \frac{\alpha_{0}-\alpha_{1}+c}{\beta_{1}-\beta_{0}}$ changes with the business cycle. One would expect $z^{*}$ to be more elastic for children of low-skilled parents because of differences in returns to education by parental occupation, possibly because of complementarities with earlier investments (Cunha and Heckman (2008), Cunha et al. (2010)); or because of differences in discount rates (Tanaka et al. (2010), Banerjee and Mullainathan (2010)). Another source of heterogeneity could be an increased children's attention towards employment prospects when making their schooling choices after changes in parental labor market success due to the business cycle, as shown by Huttunen and Riukula (2017). Second, besides the heterogeneity in the changes in $z^{*}$, it is very likely that the number of students at the margin where economic conditions change the optimal level of schooling $H^{\prime}(z *)$ differs by parental occupation. In particular, we would expect a larger share of children of low-skilled parents to be at the margin between obtaining post-compulsory schooling (or college) or not.

\subsection{The occupational intergenerational mobility implications of the busi- ness cycle}

In this model, the notion of wage upon which the educational decision is taken is lifetime earnings adjusted for job amenities - that is, lifetime utility from accessing a given occupation, earnings be- 
ing only one component of that utility. Empirically, we measure this with occupational status (blue vs. white collar employment). We study how the probability of obtaining a white collar occupation conditional on parental occupation changes with the business cycle with a linear probability model.

$$
P(w c \mid b, u)=\alpha+\gamma_{0} \cdot u+\gamma_{1} \cdot \mathbf{1}(b=H)+\gamma_{2} \cdot u \times \mathbf{1}(b=H)
$$

We are interested in estimating $\gamma_{2}$. The probability of being in a white collar occupation generated by the model is the following:

$$
P(w c \mid b)=H\left(z_{b}^{*}\right) p_{b, 1}^{w c}+\left(1-H\left(z_{b}^{*}\right)\right) p_{b, 0}^{w c}, \quad \text { where } b=H, L .
$$

Where $p_{b, 1}^{w c}$ is the probability of obtaining a white collar occupation conditional on being educated and on parental occupation $b$. This simple model generates a transition matrix where $P(w c \mid b)$ depends on average educational attainment $H\left(z_{b}^{*}\right)$ - an endogenous object - and the parentaloccupation specific occupational-return to education, i.e. the difference between $p_{b, 1}^{w c}$ and $p_{b, 0}^{w c}-$ which are here considered as primitives of the model. Hence, $\gamma_{2}$ captures the following partial effect:

$$
\begin{aligned}
\gamma_{2} & =\frac{\partial P(w c \mid H, u)}{\partial u}-\frac{\partial P(w c \mid L, u)}{\partial u} \\
& =H^{\prime}\left(z_{H}^{*}\right) \frac{\partial z_{H}^{*}}{\partial u} \times\left(p_{H, 1}^{w c}-p_{H, 0}^{w c}\right)-H^{\prime}\left(z_{L}^{*}\right) \frac{\partial z_{L}^{*}}{\partial u} \times\left(p_{L, 1}^{w c}-p_{L, 0}^{w c}\right) \\
& +\left(\frac{\partial p_{H, 1}^{w c}}{\partial u} H\left(z_{H}^{*}\right)+\frac{\partial p_{H, 0}^{w c}}{\partial u}\left(1-H\left(z_{H}^{*}\right)\right)\right)-\left(\frac{\partial p_{L, 1}^{w c}}{\partial u} H\left(z_{L}^{*}\right)+\frac{\partial p_{L, 0}^{w c}}{\partial u}\left(1-H\left(z_{L}^{*}\right)\right)\right)
\end{aligned}
$$

Here, the first component (5) refers to the business cycle impact on occupational IGM that is driven by differential endogenous responses in educational attainment while the second component (6) refers to the business cycle impact that operates through changes in the transition matrix for each educational level. Regarding the second component, changes in the transition matrix for each educational level - differences in the occupational returns to education by parental occupation- could arise, for instance, due to different abilities of dealing with the scarring effects of unemployment.

Note that in our model, holding education constant is equivalent to holding $z^{*}=\left[z_{H}^{*}, z_{L}^{*}\right]$ fixed 
to a specific value. Denoting this specific value by $\underline{z}, \gamma_{2}$ can be expressed as:

$$
\begin{aligned}
\left.\gamma_{2}\right|_{z *=\underline{z}} & =\left.\frac{\partial P(w c \mid H, u)}{\partial u}\right|_{z_{H}^{*}=z_{H}}-\left.\frac{\partial P(w c \mid L, u)}{\partial u}\right|_{z_{L}^{*}=z_{L}} \\
& =\left(\frac{\partial p_{H, 1}^{w c}}{\partial u} H\left(z_{H}^{*}\right)+\frac{\partial p_{H, 0}^{w c}}{\partial u}\left(1-H\left(z_{H}^{*}\right)\right)\right)-\left(\frac{\partial p_{L, 1}^{w c}}{\partial u} H\left(z_{L}^{*}\right)+\frac{\partial p_{L, 0}^{w c}}{\partial u}\left(1-H\left(z_{L}^{*}\right)\right)\right)
\end{aligned}
$$

Therefore the difference between $\gamma_{2}$ and $\left.\gamma_{2}\right|_{z *=\underline{z}}$ captures the component of the business cycle impact on occupational IGM that is due to endogenous educational responses to the business cycle. Empirically, we estimate equation (3) conditioning or not on a measure of educational attainment. The gap between the estimated coefficients captures the contribution of endogenous responses of education to the business cycle to the overall effect of the business cycle on occupational IGM. On the other hand, $\left.\gamma_{2}\right|_{z *=\underline{z}}$ captures the IGM-implications of the business cycle that are related to changes in the transition matrix by education level.

To sum up, in the model occupational IGM is a function of educational attainment across parental occupations and of parental occupation-specific occupational returns to education. Accordingly, business cycles can affect the occupational IGM either through endogenous educational responses or through changes in the occupational returns to education. By estimating the model holding or not education fixed, we can assess the share of the occupational IGM implications of the business cycle that is due to either mechanism. We now present to the data we will use in the empirical applications.

\section{Institutional Setting, Data and Descriptive Statistics}

\subsection{The French Educational System}

The French educational system contains three main stages: elementary education, for children aged six to eleven; secondary education - which is itself divided into middle school and high school - and tertiary education. The minimum school leaving age is 16 years.

Importantly for our study, public education in France is centrally financed and supervised at the local level by Académies which are in charge of implementing the national educational program whose content is determined by the Ministry of Education. Note that each province (département), the level at which we measure local unemployment, is fully included in a single Académie. As the allocation of funds and manpower is mostly based on pupils' enrollment, spending per student is 
rather homogeneous across Académie. ${ }^{5}$

Public schools accounted for $80 \%$ of secondary school enrollment at the national level in 2000. This share has been stable over time (DEPP, 2017). French private schools account for the remainder. It is worth noting that an overwhelming majority of them are publicly funded. To receive public funds, private schools accept to be supervised by the Ministry of Education in terms of curriculum, human resources management as well as, most importantly for our purpose, the fees they can charge. The fees are essentially restricted to not exceed the costs faced by the school. As a result, they tend to be modest, in the range of $€ 500$ to $€ 2000$ euro year.

Consequently, the costs of post-compulsory secondary education appear to be rather low. A recent survey indicates that households have a gross spending (without accounting for various government transfers, some of which are mean-tested) of about $€ 1200$ per enrolled high school student over the school year (academic year 2014/2015, Rudolf (2015)). Less than 10\% of the overall spending was related to fees and insurance costs. Other important cost items are related to food and boarding (40\%), transportation (10\%), as well as books and other school supplies (15\%). ${ }^{6}$ Perhaps in part as a consequence of these rather low costs of post-compulsory secondary education, the 15-19 year-old enrollment rate in France in 2015 (84.1\%) was above that of the UnitedStates $(79.5 \%)$, the United-Kingdom $(82.8 \%)$, or the OECD (unweighted) average $(82.8 \%) .^{7}$ The costs of post-compulsory tertiary education have been documented to be much larger, and are estimated to be around $€ 6300$ as of 2010 by Fack and Grenet (2015), mostly as a result of higher living expenses. A system of grants cover however a substantial share of this financial burden for low-income households. ${ }^{8}$

\subsection{Data}

We use the French Labor Force Survey, from 1990 to 2014, merged with national and provincial unemployment rate data from 1982 to $2014 .{ }^{9}$ We keep all individuals older than 26 at the time

\footnotetext{
${ }^{5}$ For instance, the interdecile ratio in terms of spending per student at the secondary level was only 1.14 in 2010 , with a coefficient of variation of $9 \%$. Source: Authors computation based on data from Ministère de l'Éducation nationale.

${ }^{6}$ All statistics are obtained by aggregating the Columns LP and LEGT of Table 2 and 3 in Rudolf (2015). While euro 1200 per year might appear substantial, it is unclear whether all the included costs would disappear if the student was to drop out and look for work (e.g. food, clothing ...).

${ }^{7}$ Source: OECD enrollment database.

${ }^{8}$ See Fack and Grenet (2015), in particular their appendix A, for a thorough description of the cost share covered by the grant system as a function of parental category.

${ }^{9}$ From 1982 to 2002, the LFS is yearly, from 2003 onwards, it is quarterly. The version of the LFS used are referenced as follows: Enquête Emploi en continu (version FPR) - 1982/2014, INSEE (Institut national de la statistique et des études économiques) [producteur], ADISP-CMH [diffuseur].
} 
of the survey (i.e., individuals who are unlikely to further increase their educational attainment); and for which we have information on the unemployment rate at the time of choosing schooling (i.e., those born between 1965 and 1988). We obtain a sample of about 200,000 individuals, corresponding to 23 cohorts across 96 provinces, with an average and a median $N$ of 300 and 223 individuals by cohort-province. The average age of individuals at the time of the survey is 33 , with a maximum age of 48. For every individual, we observe educational attainment and both own and parental labor market occupation.

We classify individuals (and parents) as being blue or white collar workers. In particular, blue collar workers are employee and (factory) worker (respectively employés and ouvriers in French), and white collar workers are executive or other high position as well as Intermediate occupations (respectively cadres and professions intermédiaires in French). Because we focus on intergenerational mobility through the lenses of education, we choose to focus on individuals whose parents main occupation is in the salaried sector, distinguishing between white and bluecollar jobs. ${ }^{10}$ Accordingly, we exclude individuals whose parents are/were self-employed - in occupations such as farmer, craftsman or shopkeeper. Individuals who are currently unemployed but worked at some point of their life document the occupation associated with their last job. They are therefore included in the baseline estimation sample based on that last occupation. ${ }^{11}$

We additionally exclude individuals who are themselves employed in the self-employed occupations of farmers, shop and business owners. This last restriction is motivated by two main reasons. First, the role of education is likely to be less determinant in accessing self-employed occupations than salaried ones. Notably, becoming self-employed might be greatly facilitated by the intergenerational transmission of financial wealth to provide start-up capital - for opening a shop or a restaurant for instance. For instance, Bauer et al. (2017) show that receiving a donation from one's parents increases substantially the likelihood of becoming self-employed. The focus on ultimately not self-employed children allows us to abstract from such considerations. Second, it is much harder to rank self-employed occupations with respect to other occupations. For instance, the self-employed occupation coded as "business owner" might refer to highly educated business leaders as well to initially self-employed bricklayers who manage to grow their company. ${ }^{12}$

\footnotetext{
${ }^{10}$ Indeed, the intergenerational mobility of children of self-employed workers is likely to be affected by the transmission of physical or reputational capital, e.g. business goodwill, or of professional rents in the case of licensed occupations (see e.g. Mocetti, 2016).

${ }^{11}$ Individuals who have been unemployed for their entire professional life are attributed a separate occupation. While they are excluded from the baseline sample, all results presented in this paper are robust to their inclusion in the sample. See Section OA1 of the Online Appendix.

${ }^{12}$ This restriction results in reduction of the estimation sample of about 3.9\%. All results are robust to the inclusion of these individuals to the estimation sample. Results are presented in Section OA1 of the Online Appendix.
} 
The education variable describes the highest degree obtained by the individual, which can be one of the following: no diploma, end of middle school degree (9th grade), early vocational training degree (CAP), Technical degree, technical or vocational senior high school degree (Tech. and Pro. Baccalauréat), general senior high school degree (Baccalauréat), Undergraduate diploma (two years after the Baccalauréat), Bachelor's degree (three years after the Baccalauréat), Graduate diploma (four years after the Baccalauréat), and higher degree (Master's and $\mathrm{PhD}$ ). We consider as individuals with no post-compulsory degree those who hold no diploma or just an end of middle school degree. The rest are classified as holding a post-compulsory degree. People holding a degree strictly above high-school are classified as being college-educated and having completed some higher education.

Data on the local unemployment rate are provided by INSEE (Institut national de la statistique et des études économiques). The unemployment rate is computed using administrative data on both job seekers and local employment. While the exhaustive nature of the data ensures the quality of the unemployment rate at the local level over the period, the data do not allow us to obtain unemployment rates by age, skill or gender. ${ }^{13}$

\subsection{Descriptive Statistics}

Table 1 and table 2 report descriptive statistics. In table 1, the sample is split according to the workers' skill category once in the labor market. Throughout the paper, we use white collar and high-skilled jobs interchangeably. The descriptive statistics show that white collar workers are more likely to hold post-compulsory degrees; and much more likely to hold college degrees. More than half of the white collar workers had a white collar father, and compared to children of blue collar workers, they are more than twice as likely to have a white-collar father. On the other hand, in table 2 the sample is split according to the workers' parental occupation. The descriptives show that children of white collar workers are more likely to hold post-compulsory degrees; and much more likely to hold college degrees. Moreover, two thirds of white collar children end up in white collar occupations, and compared to children of blue collar workers, they are twice as likely to be employed as a white collar workers. The differences in educational attainment by parental occupation (table 2) are smaller than the differences by own skill (table 1),

\footnotetext{
${ }^{13}$ It is calculated by combining administrative data from the public employment agency on job seekers, and several other administrative as well as survey data to build reliable statistics on local employment. While we cannot build local statistics on unemployment by skill-level, at the national level, we find a higher unemployment rate for individuals with no post-compulsory education ( +4.8 pp over the 1982 to 2004 period). Both skill-specific unemployment rates are however strongly related to the aggregate one: the coefficient of correlation is 0.91 for workers with no postcompulsory education and 0.97 for individuals with a post-compulsory degree.
} 
suggesting that there is some IGM. However, the differences remain large, indicating a substantial amount of intergenerational persistence in economic status. In addition, the descriptives suggest that our binary measure of economic status is a meaningful measure. Tables 3 and 4 show that the intergenerational persistence is not only driven by educational attainment, since it is also large within maximum educational attainment cells.

Finally, figure 1 displays the Parental Occupation (PO) gap (which refers to the difference between having a white collar father (high PO) or a blue collar father (low PO)) in access to white collar jobs; and figure 2 displays the relationship between the PO gap in post-compulsory attainment (in our conceptual framework, denoted by $H\left(z_{H}^{*}\right)-H\left(z_{L}^{*}\right)$ ) and the PO gap in the probability of obtaining a white collar job. The figures display large differences in labour market success by parental occupation, and a positive correlation between the parental occupation gap in post-compulsory educational attainment and the parental occupation gap in the probability of obtaining a white collar job. ${ }^{14}$

Table 1 - Occupation measure and covariates

\begin{tabular}{lccc}
\hline \hline & All & Blue Collar & White Collar \\
\hline Post Compulsory Education & 83.66 & 74.19 & 95.66 \\
& $(36.97)$ & $(43.76)$ & $(20.38)$ \\
University Degree & 39.98 & 14.46 & 72.30 \\
& $(48.99)$ & $(35.17)$ & $(44.75)$ \\
White Collar Father & 0.361 & 0.218 & 0.543 \\
& $(0.480)$ & $(0.413)$ & $(0.498)$ \\
Unemployment rate at age 16 & 8.809 & 8.769 & 8.861 \\
& $(1.043)$ & $(1.037)$ & $(1.049)$ \\
\hline Observations & 198063 & 110672 & 87391 \\
\hline \hline Standard deviation in parenthesis & & &
\end{tabular}

Standard deviation in parenthesis

\section{Empirical Specification}

Our baseline specification is the following:

$$
\begin{aligned}
\text { Outcome }_{i}= & \beta_{0}+\beta_{1} \mathrm{WCF}_{i}+\beta_{2} U_{16, i}^{b p l} \\
& +\beta_{3}\left(U_{16}^{b p l} \times \mathrm{WCF}\right)_{i}+X_{i}^{\prime} \beta_{4}+\epsilon_{i}
\end{aligned}
$$

\footnotetext{
${ }^{14}$ The two series (raw and smoothed) are plotted against time in Figure A1 in the Appendix.
} 
Table 2 - Parental Occupation measure and covariates

\begin{tabular}{lccc}
\hline \hline & All & Blue Collar Father & White Collar Father \\
\hline Post Compulsory Education & 83.66 & 78.54 & 92.72 \\
& $(36.97)$ & $(41.06)$ & $(25.98)$ \\
University Degree & 39.98 & 26.73 & 63.40 \\
& $(48.99)$ & $(44.25)$ & $(48.17)$ \\
White Collar & 44.12 & 31.60 & 66.26 \\
& $(49.65)$ & $(46.49)$ & $(47.28)$ \\
Unemployment rate at age 16 & 8.809 & 8.780 & 8.862 \\
& $(1.043)$ & $(1.040)$ & $(1.047)$ \\
\hline Observations & 198063 & 126505 & 71558 \\
\hline \hline Standard deviation in parenthesis & & &
\end{tabular}

Table 3 - Own and Parental Occupation, conditional on Post Comp. Education

\begin{tabular}{lccc}
\hline \hline & BC Father, only PC & WC Father, only PC & All, only PC \\
\hline White Collar & 19.46 & 36.54 & 23.60 \\
& & \\
\hline Observations & 65540 & 20977 & 86517 \\
\hline \hline & BC - Blue Collar, WC - White Collar, PC - Post Compulsory \\
\multicolumn{2}{l}{ Only individuals with PC but no University Degree }
\end{tabular}

Table 4 - Own and Parental Occupation, conditional on College Education

\begin{tabular}{lccc}
\hline \hline & BC Father, only UD & WC Father, only UD & All, only UD \\
\hline White Collar & 73.10 & 84.74 & 79.77 \\
& & 45392 & 79230 \\
\hline Observations & 33838 & &
\end{tabular}



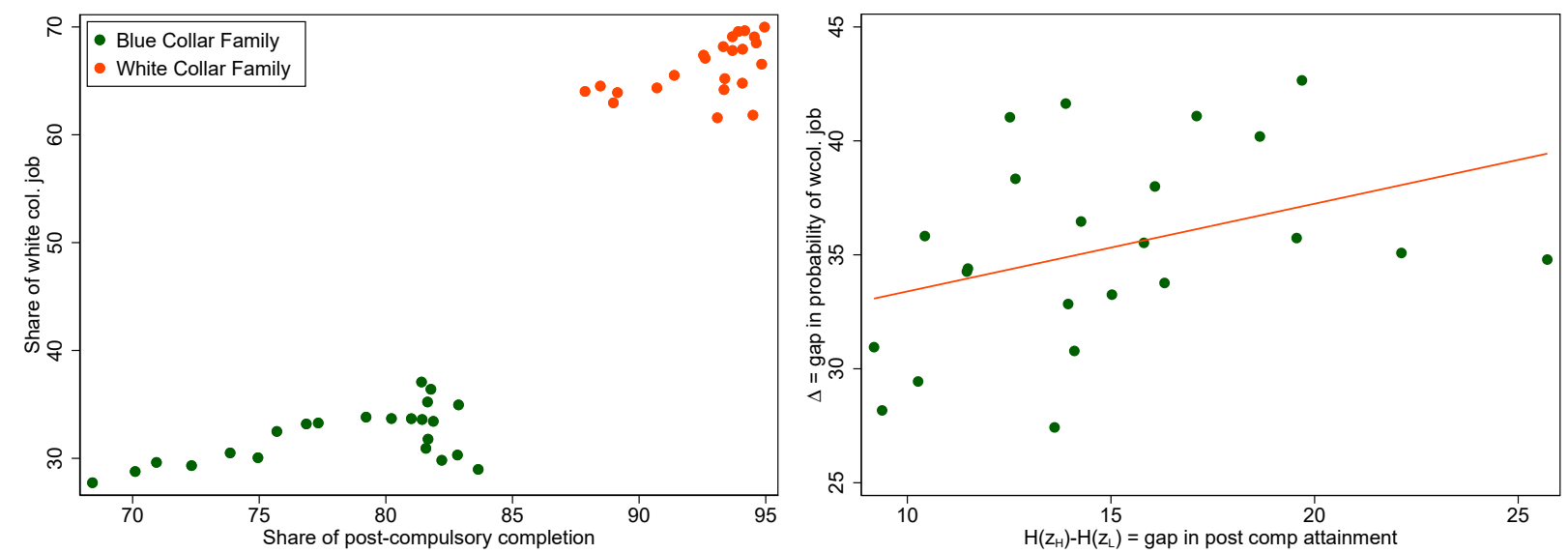

Note: Figure 1 plots the share of white collar against the share of post-compulsory attainment by cohort for the different cohort presented. Figure 2 plots the gap in access to white collar job versus the gap in terms of post-compulsory attainment, where the gap is computed between white and blue collar parental occupation. Cohorts included are those born between 1966 and 1988 included as described in 3.2.

where $U_{16}^{b p l}$ refers to the unemployment rate prevailing in the place of birth of individual $i$ when she was 16 (i.e., $b p l$ stands for birthplace). We regress the outcome of interest of individual $i$ on a dummy for having a white collar father $\left(W C F_{i}\right)$, the unemployment rate at age 16 , and the interaction between the two. Our coefficient of interest is $\beta_{3}$. Since children of white collar fathers have better outcomes on average, a negative $\beta_{3}$ would imply that the parental occupation gap is smaller for cohorts exposed to bad economic conditions at age 16.

We estimate this regression on two outcomes. To measure Educational IGM, we will use a dummy for holding a post-compulsory degree; and a dummy for holding a college degree (in the college degree specifications, our measure of economic conditions will be the unemployment rate at age 18). To measure Occupational IGM, we will use a dummy for being employed in a white collar occupation. First, we present results exploiting variation in national economic conditions, then we exploit variation in local (province level) conditions as well. Since we observe the individuals' province of birth, we will use the unemployment rate corresponding to that province, to avoid biases due to family sorting across provinces due to labor market conditions. We focus on the unemployment rate at age 16 because it is the first period in which individuals have to make a choice, given that all individuals are enrolled in school until age 16. Moreover, this minimizes the simultaneity bias between unemployment rates and school enrollment rates.

Our most demanding specification will include province by year of birth fixed effects, that absorb all unobserved heterogeneity within a cohort in a province, province by parental occupation fixed effects, that absorb all time-invariant differences in unobserved differences between 
white and blue collar workers that might systematically change across provinces, and province by parental occupation time trends. Occupational IGM regressions feature additional controls survey year by birth year fixed effects and age at survey by parental occupation fixed effects-, to allow for heterogeneous career profiles by age and parental occupation (Lee and Solon, 2009). All regressions are estimated by OLS, and include a gender dummy as a control. Standard errors are clustered at the province by parental occupation level, except for regressions exploiting variation in the national unemployment rate, when we report White-Huber heteroskedasticity-robust standard errors.

\section{Main Results}

\subsection{Educational Intergenerational Mobility}

We start with very simple correlations, and move step by step towards more flexible specifications. The first column in table 5 reports the estimates of a regression of holding a post-compulsory degree on the national unemployment rate at age 16, a dummy for having a white collar father, and its interaction, without any other controls. The results show that there is positive relationship between bad economic conditions at age 16 and the probability of holding a post-compulsory degree, and that children of high skilled parents are significantly more likely to obtain post-compulsory education. Our parameter of interest shows that the children of the low skilled are the most countercyclical. This means that cohorts deciding on education in recessions are more intergenerationally mobile. Including year of birth fixed effects and province by parental occupation fixed effects does

not significantly change the results. For every regression, we report $\widehat{\beta} \times \frac{\Delta U_{25}^{75}}{\overline{g a p}}$, which measures by how much a variation in the unemployment rate from the 75 th to the 25 th percentile of the distribution (which we denote $\Delta U_{25}^{75}$ ) changes the educational gap between children of blue and white collar workers as a fraction of the unconditional sample average gap (denoted $\overline{\text { gap}})$. According to these first estimates, being exposed to a high national unemployment rate at the moment of choosing post-compulsory education reduces the average parental occupation gap in post-compulsory educational attainment by slightly more than $10 \%$.

Table 6 reports estimates of the same relationship, but exploiting variation in economic conditions at the province level. These regressions include province by parental occupation fixed effects and either cohort fixed effects or cohort by province of birth fixed effects. The estimates in table 6 indicate that being exposed to a high regional unemployment rate (75th vs. 25 th per- 
Table 5 - Post-compulsory schooling and national unemployment rate at 16

\begin{tabular}{lccc}
\hline & $(1)$ & $(2)$ & $(3)$ \\
& PostComp & PostComp & PostComp \\
\hline$U_{16, n a t}$ & $3.077^{* * *}$ & & \\
& $(0.109)$ & & $-1.638^{* * *}$ \\
$U_{16, n a t} \times$ WCF & $-1.700^{* * *}$ & $-1.635^{* * *}$ & $(0.165)$ \\
& $(0.142)$ & $(0.161)$ & \\
WCF & $28.92^{* * *}$ & $27.89 * * *$ & \\
& $(1.285)$ & $(1.549)$ & $\checkmark$ \\
\hline Adjusted $R^{2}$ & 0.043 & 0.054 & $\checkmark$ \\
Cohort FE & & $\checkmark$ & $14.2 \mathrm{pp}$ \\
Prov. FE & & $\checkmark$ & $-11.4 \%$ \\
Prov. $\times$ Parental Occ. FE & $14.2 \mathrm{pp}$ & $14.2 \mathrm{pp}$ & 198063 \\
Mean Gap in Outcome & $-11.9 \%$ & $-11.4 \%$ & \\
$\widehat{\beta} \times \frac{\Delta U_{25}^{75}}{\text { gap }}$ & 198063 & 198063 & \\
Observations & & & \\
\hline
\end{tabular}

Notes: WCF stands for white collar father. Robust standard errors in parentheses. All regressions control for gender. $* \mathrm{p}<0.1, * * \mathrm{p}<0.05, * * * \mathrm{p}<0.01$

Table 6 - Post-compulsory schooling and provincial unemployment rate at 16

\begin{tabular}{lcc}
\hline & $(1)$ & $(2)$ \\
& PostComp & PostComp \\
\hline$U_{16, d}^{b p l}$ & $0.568^{* * *}$ & \\
& $(0.163)$ & \\
$U_{16, d}^{b p l} \times \mathrm{WCF}$ & $-1.300^{* * * *}$ & $-1.214^{* * *}$ \\
& $(0.141)$ & $(0.0962)$ \\
\hline Adjusted $R^{2}$ & 0.054 & 0.054 \\
Cohort FE & $\checkmark$ & $\checkmark$ \\
Prov. $\times$ Parental Occ. FE & $\checkmark$ & $\checkmark$ \\
Prov. $\times$ Cohort FE & $14.2 \mathrm{pp}$ & $14.2 \mathrm{pp}$ \\
Mean Gap in Outcome & $-25.6 \%$ & $-23.9 \%$ \\
$\widehat{\beta} \times \frac{\Delta U_{25}^{75}}{\text { gap }}$ & 198063 & 198046 \\
Observations & & \\
\hline
\end{tabular}

Notes: WCF stands for white collar father. Robust standard errors in parentheses - clustered at the province $\times$ white collar family level. All regressions control for gender. $* \mathrm{p}<0.1, * * \mathrm{p}<0.05, * * * \mathrm{p}$ $<0.01$

centile) at the moment of choosing post-compulsory education reduces the parental occupation gap in post-compulsory educational attainment by more than $20 \%$.

Table 7 reports estimates with the same specification and variation as in table 6 , but with a 
dummy for holding a college degree as an outcome, and using unemployment rates at age 18 rather than at age 16 as an explanatory variable. The estimates in table 7 show that obtaining a college degree is pro-cyclical. One explanation for this is that college is more expensive than other forms of post-compulsory education. At the same time, note that we observe that children of highskilled families are more responsive to the business cycle. This could be due to self-selection. In our main analysis we study post-compulsory education and economic conditions at age 16 because it is when all students, independently of their parental occupation, must take their first educational decision, since all students must reach compulsory education. However, individuals who decide upon higher education are those who remained in post-compulsory education between age 16 and 18. At this margin, the children of blue collar families are less numerous and possibly more positively selected, given that they face less favorable conditions to get a post-compulsory degree.

While it is difficult to test whether this is precisely the mechanism, and the intuition for this result is not exactly the same as for post-compulsory schooling, this result is interesting because it has the same implication regarding the effect of the business cycle on intergenerational mobility through behavioral responses in educational attainment - again, the children of blue collar workers are relatively less pro-cyclical. The point estimates in table 7 suggest that being exposed to a high provincial unemployment rate at the typical moment of choosing college education reduces the parental occupation gap in college degree attainment by around 4\%. Table A2 in the Appendix reports results both for post-compulsory schooling and college, allowing by differential trends at the province by parental occupation level. The coefficient of interest for post-compulsory education becomes smaller in magnitude, but in both cases the qualitative implications remain similar, economically and statistically significant.

The model estimated so far is a linear probability model. This might be problematic given that a high share of individuals in our sample obtain post-compulsory education - about $83 \%$ as indicated in Table 1. We assess the robustness of this modeling choice by constructing a variable measuring the length of initial schooling in years. We use this outcome as the dependent variable in a regression whose specification is otherwise identical to those presented in Table 6 and 7. Results are reported in table A1 in the Appendix. Looking at Column (2) which reports estimates from a specification including (province $\times$ cohort) and (province $\times$ parental occupation) fixedeffects, we see a significantly negative coefficient of about -0.10 . This coefficient implies that a rise in local unemployment equal to the interquartile distance is associated with a decline in the gap in length of schooling of about $13 \%$ of the sample average gap in terms of years of schooling 
Table 7 - College degree and provincial unemployment rate at 18

\begin{tabular}{lcc}
\hline & $\begin{array}{c}(1) \\
\text { College }\end{array}$ & $\begin{array}{c}(2) \\
\text { College }\end{array}$ \\
\hline$U_{18, d}^{b p l}$ & $-0.371^{*}$ & \\
& $(0.191)$ & \\
$U_{18, d}^{b p l} \times \mathrm{WCF}$ & $-0.561^{* *}$ & $-0.546^{* * *}$ \\
& $(0.219)$ & $(0.149)$ \\
\hline Adjusted $R^{2}$ & 0.159 & 0.159 \\
Cohort FE & $\checkmark$ & $\checkmark$ \\
Prov. $\times$ Parental Occ. FE & $\checkmark$ & $\checkmark$ \\
Prov. $\times$ Cohort FE & $36.7 \mathrm{pp}$ & $36.7 \mathrm{pp}$ \\
Mean Gap in Outcome & $-4.600 \%$ & $-4.5 \%$ \\
$\widehat{\beta} \times \frac{\Delta U_{25}^{75}}{\text { gap }}$ & 198063 & 198046 \\
Observations & & \\
\hline
\end{tabular}

Notes: WCF stands for white collar father. Robust standard errors in parentheses - clustered at the province $\times$ white collar family level. All regressions control for gender. $* \mathrm{p}<0.1, * * \mathrm{p}<0.05, * * * \mathrm{p}$ $<0.01$

between children of white collar and blue collar workers - which is of about 2.2 years.

\subsection{Occupational intergenerational mobility}

The previous results show that cohorts exposed to bad economic conditions at the moment of making important schooling choices are more intergenerationally mobile in terms of educational attainment. We now ask whether these cohorts perform differently in the labour market as well. To this aim, we study how exposure to the business cycle relates to occupational IGM, defined as the difference in the probability of having a white collar job between those with a white-collar father and those with a blue-collar father. According to our conceptual framework of positive selection into education by ability, with complementarities between ability and schooling, the business cycle compliers are likely to have relatively low returns to schooling, which could explain a null effect on occupational IGM in spite of a positive effect on educational IGM. On the other hand, we have seen in table 5 that on average, those cohorts obtain more schooling, and in a general equilibrium framework this could lower the return to schooling for the whole cohort, which would reinforce the effect on educational IGM and lead to a higher occupational IGM. ${ }^{15}$

To answer this question, we estimate the same regressions, using a dummy for being employed as a white collar as an outcome. The empirical specification is very similar. Given that we measure

\footnotetext{
${ }^{15}$ This would happen as long as the scarring effects of unemployment for those choosing not to go to school are large enough so that the returns to schooling within the cohort end up increasing.
} 
the labor market outcome of individuals at different ages and in different years, we add survey year by birth year fixed effects. To further allow for heterogeneous career profiles by age and parental occupation (Lee and Solon, 2009), we include age at survey by parental occupation fixed effects.

We start with correlations at the national level. Table 8 reports estimates of the relationship between the national rate of unemployment at age 16 and the probability of being employed in a white collar occupation, by parental occupation. The patterns in this table are very similar to those in table 5: individuals in cohorts exposed to worse economic conditions at age 16 are significantly more likely to become white collar workers, and this pattern is stronger for the children of the low skilled, that have a lower unconditional probability of becoming white collar workers. The point estimates in table 8 suggest that being exposed to a high national unemployment rate at the moment of choosing post-compulsory education reduces the intergenerational elasticity of white collar employment by around $1.7 \%$.

Table 8 - Occupational status and national unemployment rate at 16

\begin{tabular}{lcccc}
\hline & $(1)$ & $(2)$ & $(3)$ & $(4)$ \\
& White Collar & White Collar & White Collar & White Collar \\
\hline$U_{16, \text { nat }}$ & $1.680^{* * *}$ & & & \\
& $(0.126)$ & & & \\
$U_{16, \text { nat }} \times$ WCF & $-0.481^{* *}$ & $-0.621^{* * *}$ & $-0.606^{* *}$ & $-0.595^{* * *}$ \\
& $(0.210)$ & $(0.224)$ & $(0.240)$ & $(0.245)$ \\
WCF & $38.82^{* * *}$ & & & \\
& $(1.867)$ & & & \\
\hline Adjusted $R^{2}$ & 0.114 & 0.123 & 0.130 & $\checkmark .130$ \\
Age $\times$ Parental Occ. FE & & $\checkmark$ & $\checkmark$ & $\checkmark$ \\
Cohort $\times$ Survey FE & & $\checkmark$ & $\checkmark$ & $\checkmark$ \\
Prov. FE & & & & \\
Prov. $\times$ Parental Occ. FE & $34.7 \mathrm{pp}$ & $34.7 \mathrm{pp}$ & $34.7 \mathrm{pp}$ & $34.7 \mathrm{pp}$ \\
Mean Gap in Outcome & $-1.4 \%$ & $-1.8 \%$ & $-1.7 \%$ & $-1.7 \%$ \\
$\widehat{\beta} \times \frac{\Delta U_{25}^{75}}{\text { gap }}$ & 198109 & 198109 & 198109 & 198109 \\
Observations & & & & \\
\hline
\end{tabular}

Notes: Robust standard errors in parentheses. All regressions control for gender. $* \mathrm{p}<0.1, * * \mathrm{p}<$ $0.05, * * * \mathrm{p}<0.01$

Table 9 reports estimates of the same relationship, but exploiting variation in local economic conditions. The results are stable across specifications and have similar implications. The point estimates in table 9 suggest that being exposed to a high provincial unemployment rate at the moment of choosing post-compulsory education reduces the intergenerational elasticity in white collar employment by around $4.4 \%$. Table A3 in the Appendix reports very similar results for 
provincial unemployment rates at age 18. Table A4 in the Appendix reports results that control for province by parental occupation trends, with similar point estimates as well.

Table 9 - Occupational status and provincial unemployment rate at 16

\begin{tabular}{lccc}
\hline & $(1)$ & $(2)$ & $(3)$ \\
& White Collar & White Collar & White Collar \\
\hline$U_{16, d}^{b p l}$ & -0.0564 & -0.00342 & \\
& $(0.220)$ & $(0.214)$ & \\
$U_{16, d}^{b p l} \times$ WCF & & & $-0.540^{* * * *}$ \\
& $-0.480^{* *}$ & $-0.576^{* * *}$ & $(0.146)$ \\
\hline Adjusted $R^{2}$ & $(0.198)$ & $(0.207)$ & 0.130 \\
Prov. $\times$ Parental Occ. FE & 0.123 & 0.130 & $\checkmark$ \\
Cohort FE & $\checkmark$ & $\checkmark$ & $\checkmark$ \\
Cohort $\times$ Prov. FE & $\checkmark$ & $\checkmark$ & $\checkmark$ \\
Age $\times$ Parental Occ. FE & & & $\checkmark$ \\
Cohort $\times$ Survey FE & & $\checkmark$ & $34.7 \mathrm{pp}$ \\
Mean Gap in Outcome & $34.7 \mathrm{pp}$ & $34.7 \mathrm{pp}$ & $-4.4 \%$ \\
$\widehat{\beta} \times \frac{\Delta U_{25}^{75}}{\text { gap }}$ & $-3.9 \%$ & $-4.600 \%$ & 198092 \\
Observations & 198109 & 198109 & \\
\hline
\end{tabular}

Notes: WCF stands for white collar father. Robust standard errors in parentheses - clustered at the province $\times$ white collar family level. All regressions control for gender. $* \mathrm{p}<0.1, * * \mathrm{p}<0.05$, *** $\mathrm{p}$ $<0.01$.

Hence, overall, the results suggest that the fluctuations in schooling related to the business cycle have long-run consequences, with significant effects on the degree of IGM in white collar occupations, with exposure to different conditions leading to a change in the intergenerational whitecollar elasticity of around $4.5 \%$. It is interesting to compare the magnitude of these estimates with other case-studies. For instance, Pekkarinen et al. (2009) report a 23\% reduction in the intergenerational elasticity of income in Finland after a major educational reform that shifted the selection of students to vocational and academic tracks from age 11 to age 16, with a uniform academic curriculum on the entire cohort until age 16, reducing the heterogeneity in the quality of education. This is not surprising, since it is well documented that early investments have the largest effects on intergenerational mobility (see for instance Restuccia and Urrutia (2004)). Hence, although significant, the role of the business cycle for IGM through student choices remains considerably small compared to structural changes in the educational system. It is nonetheless likely that the structural parameters of the post-compulsory educational system (e.g. selectivity, out-of-pocket cost for students, ease of access to credit) determine how the business cycle affects schooling choices differentially across parental occupations and in turn occupational IGM. Investigating this 
question using our empirical approach would require an exploitable change in those parameters within a cohort, which we lack over the sample period. We therefore leave it to further research. ${ }^{16}$

\subsection{Educational attainment and occupational intergenerational mobility}

Our conceptual framework and our previous results highlight the role of endogenous responses in educational attainment for the effect of the business cycle on IGM. We next estimate how much of the effect on occupational IGM is driven by such changes, keeping in mind that education is an endogenous or bad control, since it is a channel, and the coefficient of interest will be biased towards zero or towards finding the opposite result. Tables 10 and 11 report occupational IGM regressions, controlling for educational attainment, which makes the unemployment rate coefficients becomes substantially smaller and less precisely estimated as well. The results show that changes in educational attainment explain most of the effect of the cycle on mobility (between $60 \%$ and $70 \%)$.

Table 10 - Occupational status and provincial unemployment rate at 16

\begin{tabular}{lccc}
\hline & $(1)$ & $(2)$ & $(3)$ \\
& PostComp & White Collar & White Collar \\
\hline$U_{16, d}^{b p l} \times$ WCF & $-1.280^{* * *}$ & $-0.540^{* * *}$ & -0.144 \\
& $(0.110)$ & $(0.146)$ & $(0.150)$ \\
PostComp & & & $0.310^{* * *}$ \\
& & & $(0.00666)$ \\
\hline Adjusted $R^{2}$ & 0.055 & 0.130 & 0.180 \\
Prov. $\times$ Parental Occ. FE & $\checkmark$ & $\checkmark$ & $\checkmark$ \\
Cohort $\times$ Prov. FE & $\checkmark$ & $\checkmark$ & $\checkmark$ \\
Age $\times$ Parental Occ. FE & $\checkmark$ & $\checkmark$ & $\checkmark$ \\
Cohort $\times$ Survey FE & $\checkmark$ & $\checkmark$ & $\checkmark$ \\
Mean Gap in Outcome & $14.2 \mathrm{pp}$ & $34.7 \mathrm{pp}$ & $34.7 \mathrm{pp}$ \\
$\widehat{\beta} \times \frac{\Delta U_{25}^{75}}{\text { gap }}$ & $-25.2 \%$ & $-4.4 \%$ & $-1.2 \%$ \\
Observations & 198046 & 198092 & 198046 \\
\hline
\end{tabular}

Notes: WCF stands for white collar father. Robust standard errors in parentheses - clustered at the province $\times$ white collar family level. All regressions control for gender. $* \mathrm{p}<0.1, * * \mathrm{p}<0.05, * * * \mathrm{p}$ $<0.01$.

\footnotetext{
${ }^{16}$ Note that it would also be interesting to measure the impact on intergenerational mobility in terms of wages. However, any analysis of the wage effect of diversity raises issues of selection, particularly in a high-unemployment country such as France. Finding a credible instrument explaining employment but not affecting wages is notoriously difficult, mainly because the exclusion restriction is difficult to justify. Moreover, wages are self-reported are in the French LFS and consequently subject to substantial measurement error (see e.g. Hagneré and Lefranc, 2006). With this caveat in mind, we conducted the analysis on wages without taking selection into account. The results are very consistent with the occupational analysis. Results are reported in Table OA2 of the online appendix.
} 
Table 11 - Occupational status and provincial unemployment rate at 18

\begin{tabular}{lccc}
\hline & $(1)$ & $(2)$ & $(3)$ \\
& College & White Collar & White Collar \\
\hline$U_{18, d}^{b p l} \times$ WCF & $-0.610^{* * * *}$ & $-0.558^{* * *}$ & -0.226 \\
& $(0.148)$ & $(0.178)$ & $(0.160)$ \\
College & & & $0.548^{* * *}$ \\
& & & $(0.00517)$ \\
\hline Adjusted $R^{2}$ & 0.160 & 0.130 & 0.376 \\
Dept $\times$ Parental Occ. FE & $\checkmark$ & $\checkmark$ & $\checkmark$ \\
Cohort $\times$ Prov. FE & $\checkmark$ & $\checkmark$ & $\checkmark$ \\
Age $\times$ Parental Occ. FE & $\checkmark$ & $\checkmark$ & $\checkmark$ \\
Cohort $\times$ Survey FE & $\checkmark$ & $\checkmark$ & $\checkmark$ \\
Mean Gap in Outcome & 36.7 pp & $34.7 \mathrm{pp}$ & $34.7 \mathrm{pp}$ \\
$\widehat{\beta} \times \frac{\Delta U_{25}^{75}}{\text { gap }}$ & $-5 \%$ & $-4.5 \%$ & $-1.8 \%$ \\
Observations & 198046 & 198092 & 198046 \\
\hline
\end{tabular}

Notes: WCF stands for white collar father. Robust standard errors in parentheses - clustered at the province $\times$ white collar family level. All regressions control for gender. $* \mathrm{p}<0.1, * * \mathrm{p}<0.05, * * * \mathrm{p}$ $<0.01$.

\subsection{Accounting for spatial mobility between birth and age 16}

Exploiting cross-sectional variation in local unemployment rates allows us to control flexibly for aggregate trends in school attainment by including cohort fixed-effects. Using birthplace unemployment rates allows us to rule out geographical sorting based on economic conditions. However, we need to assess the strength of the association between birthplace and location at 16 unemployment rate and whether it varies by parental occupation to make sure that our results are not driven by differential geographical mobility by parental occupation. ${ }^{17}$ To this aim, in this subsection we start by describing the pattern of mobility between birth and age 16 and how it affects the relationship between birthplace unemployment rate at age 16 and place of residence unemployment rate at age 16. After that, we study how this relationship varies by parental occupation and account for it by using a Two-Sample 2SLS estimator.

\subsubsection{Descriptive evidence}

In order to document the relationship between birthplace unemployment rate and place of residence unemployment rate at age 16, we use data from the same source - the French LFS - and the same cohorts (those who turned 16 in years 1982 to 2004) as in the analysis above - subsections

\footnotetext{
${ }^{17}$ See e.g. Notowidigdo (2013) for US evidence that high-skill workers are more responsive to local labor market conditions than low-skill workers.
} 
5.1 to 5.3. We focus on 16-year-old individuals about whom we know both place of birth and place of residence. For these individuals, we study the strength of this relationship and how it varies with parental occupation.

To this aim, Figures 3 display cohort and parental occupation specific OLS coefficients from the regression of the local unemployment rate in the current place of residence at age 16 (denoted $\left.U_{16}^{c u r}\right)$ onto the local unemployment rate in the place of birth $\left(U_{16}^{b p l}\right)$. The coefficients are remarkably stable over time. Moreover they are rather similar across family occupation suggesting that the differential impact of birthplace unemployment rate at age 16 on educational and occupational attainment is unlikely to reflect differential geographical mobility across parental occupations. Nevertheless, the relationship between $U_{16}^{c u r}$ and $U_{16}^{b p l}$ is significantly stronger for children of blue collar parents. To investigate this more formally we now proceed to an instrumental variables estimation whereby we instrument place of residence rate by birthplace unemployment rate at age $16 .^{18}$

Figure 3 - Difference in spatial mobility between birth and age 16 by parental occupation

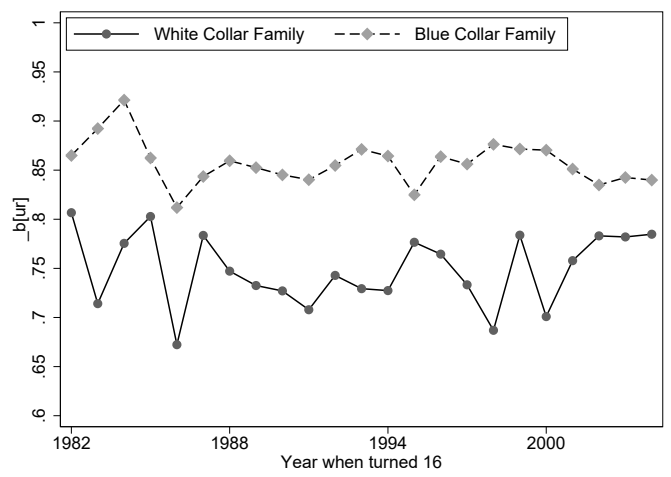

(a) Regression of $U_{16}^{c u r}$ on $U_{16}^{b p l}$

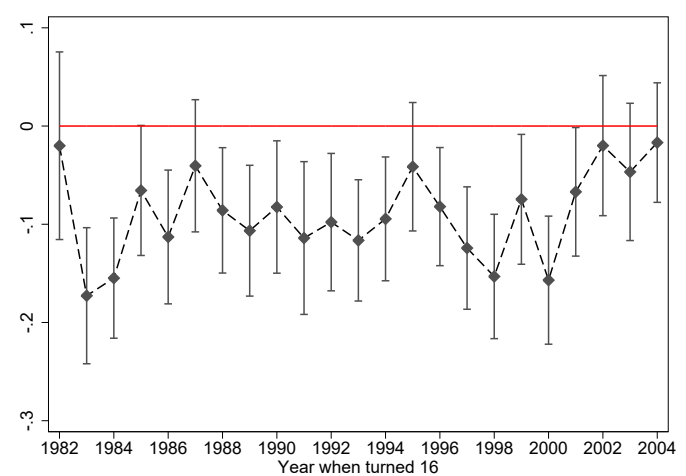

(b) Interaction: $U_{16}^{b p l} \times \mathrm{WCF}$

Note: (a) Left panel: Each dot corresponds to the coefficient of cohort-specific OLS regression of $U_{16}^{c u r}$ on $U_{16}^{b p l}$ separately for each type of parental occupation. (b) Right panel: Each dot corresponds to the coefficient of a cohort-specific regression of $U_{16}^{c u r}$ on $U_{16}^{b p l} \times$ White Collar Father with province and WCF fixed-effects. Shaded area corresponds to $95 \%$ confidence interval constructed using "parental occupation $\times$ province of birth" clustered standard errors. Cohort-specific differences are significant at the $5 \%$ level for 16 of the 23 cohorts. The regression pooled across cohorts yields a coefficient is equal -.0794 with a t-value of -12.602 .

\footnotetext{
${ }^{18}$ In subsection 6.2 , we investigate this issue by focusing on school enrollment - a different outcome than in the main analysis for which we can implement an instrumental variable approach that explicitly accounts for the slight difference in mobility across family occupations that is visible in Figure 3.
} 


\subsubsection{Correcting for differential spatial mobility by parental occupation}

In this subsection, we take stock of the slight difference in the relationship between birthplace and place of residence at age 16 by parental occupation induced by differential patterns of geographical mobility. In order to correct for it, we set-up a Two-Sample 2SLS estimation whereby place of residence unemployment rate at age 16 is instrumented by place of birth unemployment rate at age 16.

The main complication to set up an IV estimation stems from the fact that we never observe the final outcome (educational attainment or occupational status) in the same sample as both the instrument (place of birth unemployment rate) and the endogenous variable (place of residence unemployment rate). Indeed, in the main sample (which, for simplicity we will refer to as sample 1) we focus on individuals who are unlikely to increase further their educational attainment - in our analysis people of age 26 or more -, but we ignore where they were living at age 16 - we only know their place of birth, from which we infer place of birth unemployment rate at age 16. This is the sample used in the educational and occupational attainment so far.

On the other hand in the sample used in paragraph 5.4.1 above (referred to as sample 2), we observe individuals of age 16, about whom we know their place of residence at age 16 as well as their place of birth, but ignore their final educational attainment. ${ }^{19}$ This setting allows us to implement an estimation based on Two Sample 2SLS whereby the first stage is estimated using sample 2, the endogenous regressor is then predicted among observations in sample 1, and the second stage is then estimated running OLS using the generated regressor. Figure A2 in the Appendix illustrates the estimation procedure.

Results are displayed in Table 12 for specifications similar to the one in table 10 - in terms of covariates and fixed effects. Results are remarkably similar, suggesting that the non-negligible differences in geographical mobility in response to local unemployment rates across parental occupations did not substantially affect our reduced-form results.

\footnotetext{
${ }^{19}$ As indicated above, Sample 2 is also obtained from the French Labor Force Surveys, for survey years 1982-2004, restricting the sample to individuals age 16. The years 1982-2004 are chosen so that these individuals belong the same cohorts as those included in Sample 1 although they will typically come from different waves of the survey. For instance, regarding the cohort that turned 16 in year 1982, all individuals from sample 2 come from the wave 1982 of the LFS, while those included in sample 1 come from waves 1992 and beyond, as we restrict sample 1 to individuals 26 or older. Descriptive statistics on the sample are presented in Table A6.
} 
Table 12 - Two-Sample 2SLS estimates of the effect of provincial unemployment rate at 16 on post compulsory education and occupational status

\begin{tabular}{lccc}
\hline & $(1)$ & $(2)$ & $(3)$ \\
& PostComp & White Collar & White Collar \\
\hline$U_{16, d}^{c u r} \times$ High PB & $-1.479^{* * *}$ & $-0.624^{* * *}$ & -0.166 \\
& $(0.132)$ & $(0.178)$ & $(0.182)$ \\
Post Comp & & & $31.02 * * *$ \\
& & & $(0.643)$ \\
\hline Dept $\times$ PB FE & $\checkmark$ & $\checkmark$ & $\checkmark$ \\
Dept $\times$ Cohort FE & $\checkmark$ & $\checkmark$ & $\checkmark$ \\
Age $\times$ PB FE & $\checkmark$ & $\checkmark$ & $\checkmark$ \\
Cohort $\times$ Survey & $\checkmark$ & $\checkmark$ & $\checkmark$ \\
Observations & 198046 & 198092 & 198046 \\
\hline
\end{tabular}

Notes: Bootstrapped standard errors (500 replications) in parentheses - clustered at the province $\times$ white collar father level. All regressions control for gender. Each replication of the bootstrap entails the estimation of both the first and second stages of the TS-2SLS procedure. $* \mathrm{p}<0.1, * * \mathrm{p}<0.05, * * * \mathrm{p}<0.01$

\section{Heterogeneity and Robustness}

\subsection{Heterogeneity}

In the main analysis, we use retrospective information on individuals' schooling attainment. Gender, along with parental occupation and country of birth, are the only predetermined covariates to which we have access. We investigate whether there are substantial differences in our coefficient of interest, $\left(\beta_{3}\right)$, by gender, country of origin (born in France vs. born elsewhere), and between rural and urban provinces. For the latter, we use population density as a proxy, and study how the effect differs between provinces with population density above and below the median.

We present results on both educational attainment and labor market outcomes in table A5 in the Appendix. We focus on the most restrictive specification, that includes province by white collar father fixed effects and province by cohort fixed effects. When examining heterogeneity by gender, we further augment this specification to feature province by white collar father by gender fixed effects as well as province by cohort by gender fixed effects. When examining heterogeneity by country of origin, we use an analogous specification but augment the fixed effects with respect to the country of origin. The results show that the differential reaction to the business cycle by parental occupation is driven both by males and females, both by French natives and immigrants, and both by urban and rural provinces. The differential reaction by parental occupation is larger for females than for boys, and slightly smaller for foreign born individuals. Interpreting the source of these differences, however, is difficult without further data and labor market analysis - for instance, 
Aparicio-Fenoll (2016) shows that the Spanish housing boom increased men's propensity to drop out of high-school, because the construction sector labour force is mostly male.

\subsection{The reactivity of enrollment status for different ages}

The main analysis relies on schooling attainment (highest degree attained) as a measure of investment in human capital. A complementary approach is to analyze the impact of the business cycle on schooling is to investigate the impact of local unemployment rates on school enrollment. Here we present evidence confirming that the countercyclicality of the gap in school attainment across parental occupations is also reflected in terms of enrollment - an educational outcome that has been at the center of much of the previous literature. ${ }^{20}$

To do so, we estimate the impact of the local unemployment rate at age 16 on the likelihood of being in enrolled at school or not at age $17 .{ }^{21}$ We additionally examine how shocks experienced in later years might also be relevant for schooling enrollment decisions. That is, we regress enrollment at age 18 on local unemployment at 17, enrollment at age 19 on local unemployment at 18 and so forth and so on. We do so for ages 15 to 33, resulting in 19 separate regressions.

We consider the following equation:

$$
E_{a+1, i}=\alpha+\beta_{1, a} \cdot\left(U_{a}^{b p l} \times \mathrm{WCF}\right)_{i}+X_{i}^{\prime} \delta+\mathbf{F E}_{i}+\varepsilon_{i}
$$

where $E_{a g e+1, i}$ is binary variable equal to one if individual $i$ is enrolled at school at age $a+1 .^{22}$ Exogenous controls in $X$ include a binary variable for gender. $\mathbf{F E}_{i}$ refers to a set of fixed-effects that include province $\times$ parental occupation as well as province $\times$ year.

Equation 8 is a reduced-form in the sense that what matters causally for educational choices is the unemployment rate in the current location of residence at age 16 and not the one in the place of birth. However, current location unemployment rate at age $16\left(U_{a}^{c u r}\right)$ is likely to be endogenous with respect to training status at age $a+1$. For instance, one could argue that more altruistic parents are more prone to move from high to low unemployment areas and are also more likely to encourage their children to follow longer training. To circumvent this issue we can use $U_{a}^{b p l}$

\footnotetext{
${ }^{20}$ See for instance the seminal contributions of Betts and McFarland (1995) and Dellas and Sakellaris (2003)

${ }^{21}$ This is feasible because of the short longitudinal nature of the data. Individuals are, absent a special event, surveyed 3 times in the annual surveys (hence over 3 years over the survey period 1982 to 2002) and 6 times in the quarterly survey (hence over a year and a half over the survey period 2003-2004).

${ }^{22}$ The definition of schooling we consider to study enrollment is comprehensive. It is based on the nomenclature of activity status elaborated by the ILO and corresponds to the category "student or intern following a training". Descriptive statistics on this sample is provided in Table A6 in the Appendix. Note that this sample is identical to Sample 2 used in subsection 5.4, as it contains all valid observations from the LFS for 16-year-old individuals belonging to cohorts which turned 16 over the years 1982 to 2004 .
} 
as instrument for $U_{a}^{c u r}$. We know from the subsection 5.4.1 on spatial mobility that $U_{a}^{b p l}$ is a statistically strong predictor of $U_{a}^{c u r}$. Under the assumption that $U_{a}^{b p l}$ is exogenous with respect to $E_{a+1, i}$ in equation 8 , it constitutes a valid instrument for $U_{a}^{c u r} .{ }^{23}$

This analysis serves two main purposes. First, this allows us to assess whether the relationship between the local business cycle and the gap in school enrollment varies with the age of exposure. Second, the shape of the effects depending on age of exposure allows us to validate the overall analysis. Indeed, if our estimate of $\beta_{1, a}$ for $a=16$ is merely reflecting a mechanical relationship between our definition of school enrollment at time $t+1$ and local unemployment rate at time $t$ and we do not expect this mechanical relationship to vary by age, we should find relatively stable coefficients across ages of exposure to local unemployment - that is for different $a$ 's. On the other hand, if the coefficient captured a causal relationship between unemployment rates and individuals' decision to enroll or remain at school, we would expect individuals in their late teens and early 20 s to be very reactive, while we would not expect individuals in their late 20 s or 30 s to be as reactive. We would therefore expect to find negative coefficients for young individuals, and see these coefficients become closer to zero as we consider older individuals.

The latter prediction is broadly supported by results displayed in Figure 4. The figure shows the coefficients of separate IV regressions, which estimate the differential response of white versus blue collar family individuals for different ages of exposure, ranging from 15 to 33 . We see that the gap in the response is significantly negative from ages 15 to 18 , then becomes closer to zero and even switches sign for individuals aged 23 and 24 . It then declines and becomes indistinguishable from zero from age 27 onwards. As suggested by our previous results, children from white collar families are relatively less responsive to the local business cycle in their late teens. It is interesting to notice the positive coefficients around age 24 , consistent with white collar children using relatively more higher education as a buffer in response to local labor market conditions, and blue collar children adjusting relatively more through post-compulsory secondary education. Overall, these results suggest a negative causal effect of local unemployment rate on the gap in school enrollment between children of white- and blue-collar families.

\footnotetext{
${ }^{23}$ We can therefore estimate the following system of equation using 2 SLS:
}

$$
\begin{aligned}
\left(U_{a}^{c u r} \times \mathrm{WCF}\right)_{i} & =\alpha^{F S}+\beta_{1, a}^{F S} \cdot\left(U_{a}^{b p l} \times \mathrm{WCF}\right)_{i}+X_{i}^{\prime} \delta^{F S}+\mathbf{F E}_{i}+\varepsilon_{i} \\
E_{a+1, i} & =\alpha+\beta_{1, a} \cdot\left(U_{a}^{c u r} \times \mathrm{WCF}\right)_{i}+X_{i}^{\prime} \delta+\mathbf{F E}_{i}+\varepsilon_{i}
\end{aligned}
$$


Figure 4 - Differential effect of unemployment rate on enrollment - for different ages of exposure to local unemployment.

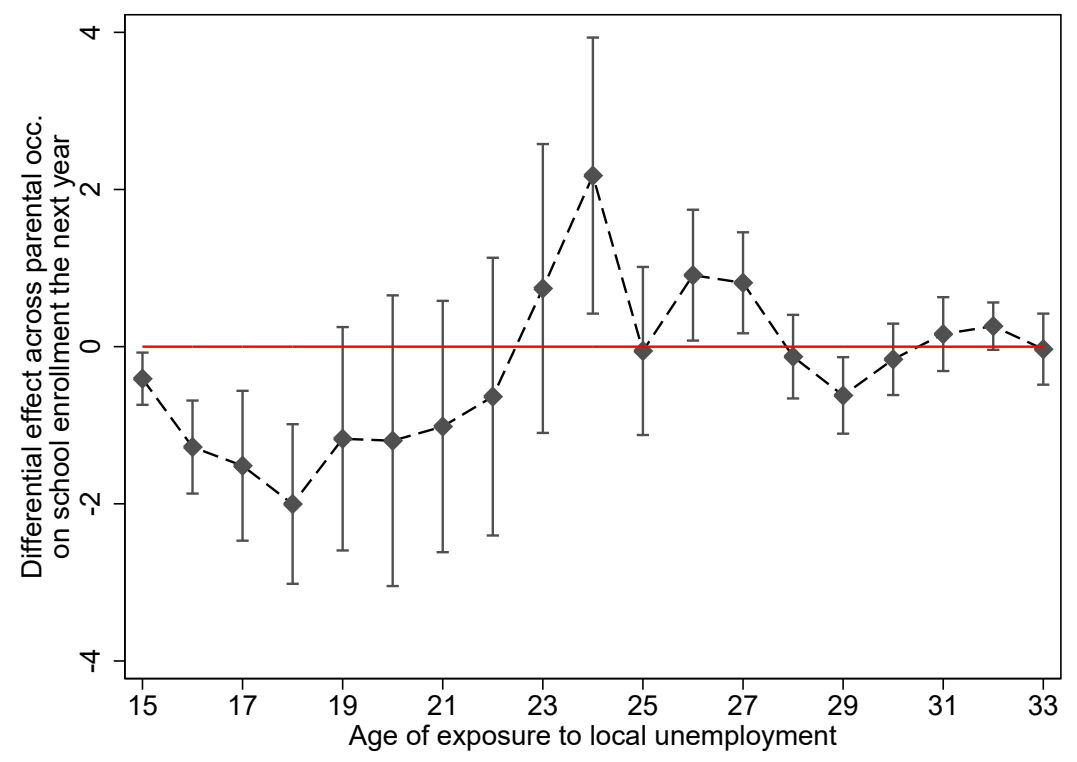

Note: Figure plots 19 IV regression coefficients that regress a binary variable for enrollment at $t+1$ on interaction between parental occupation and place of residence unemployment rate at time $t$. We estimate equation (2S) for 18 different ages of exposure to local unemployment from 15 to 33. Controls include gender and cohort as well as province $\times$ parental occupation fixed-effects. Local unemployment rate at current place of residence is instrumented by birth place unemployment rate. Shaded area correspond to $95 \%$ confidence intervals constructed using "cohort $\times$ province of birth" clustered standard errors.

\section{Conclusion}

This paper studies how economic conditions at the time of choosing post-compulsory education affect intergenerational mobility. Using a large dataset and exploiting variation in the unemployment rate in individuals' province of birth at age 16 across 96 French provinces and 23 cohorts, we find that cohorts deciding on post-compulsory education in bad economic times are more educationally intergenerationally mobile - their level of education is less related to having a white collar father. We find that this translates into differences in labor market performance, since these cohorts are also more occupationally intergenerationally mobile - their probability of having a white collar job once in the labor market is less related to having a white collar father; and that a large fraction of the effect on occupational IGM appears to be explained by differences in educational attainment. Quantitatively, our findings imply that within cohorts deciding on education in a high moment of the cycle (25th percentile of unemployment rate), the difference in the probability of having a white collar job between children of white and blue collar fathers increases by $5 \%$, compared to cohorts deciding in a low moment of the cycle (75th percentile). Hence, our findings 
suggest that especially for children of the low skilled, changes in the opportunity cost of schooling have more traction in driving schooling decisions than changes in the ability to pay induced by the business cycle. Our results unveil a channel through which the transmission of economic advantage arises and fluctuates across cohorts, contributing to the literature on the determinants of inter-generational mobility within countries - an exercise that is very data demanding. The findings complement existing evidence outlining that economic shocks at crucial stages in life can have significant long-run effects. From a policy perspective, the results suggest that providing information on the long-run benefits of schooling might be particularly important during booms, to avoid decreases in intergenerational mobility due to its heterogeneous effects on educational attainment by parental occupation. However, unsurprisingly, the magnitude of our estimates is small compared to the effects of aspects of the educational systems, such as tracking or the heterogeneity in the quality of early education, on intergenerational income mobility. For instance, Pekkarinen et al. (2009) report a $23 \%$ reduction in the intergenerational elasticity of income in Finland after a major educational reform that shifted the selection of students to vocational and academic tracks from age 11 to age 16 , reducing the heterogeneity in the quality of education.

Finally, this paper contributes to the ongoing policy debate regarding the strong tendency of the French educational system to reproduce social inequality in terms of school performance (OECD, 2016). ${ }^{24}$ Our results suggest that the contribution of a schooling system to social mobility depends not only on whether it is socially biased against enrolled students but also on access. In the French case, the low cost of post-compulsory schooling might explain in part the relatively more countercyclical enrollment responses that we document by 16 -year-olds raised in blue-collar families. Another potential feature of the French schooling system that might explain the present results is its centralized financing which is likely to limit the impact of local economic shocks on schools' resources (as opposed to what has been documented in the US, see Feler and Senses, 2017).

\section{References}

AAROnson, D. and MAZUMder, B. (2008). Intergenerational Economic Mobility in the United States, 1940 to 2000. Journal of Human Resources, 43 (1).

Altonji, J. G., Kahn, L. B. and Speer, J. D. (2016). Cashier or Consultant? Entry Labor Market Conditions, Field of Study, and Career Success. Journal of Labor Economics, 34 (S1), S361 - S401.

\footnotetext{
${ }^{24}$ See for instance New York Times, "The Stranglehold on French Schools", September 11th, 2015
} 
Angrist, J. D. and Krueger, A. B. (1992). The effect of age at school entry on educational attainment: An application of instrumental variables with moments from two samples. Journal of the American Statistical Association, 87 (418), 328-336.

Aparicio-Fenoll, A. (2016). Returns to education and educational outcomes: The case of the spanish housing boom. Journal of Human Capital, 10 (2), 235-265.

Arulampalam, W. (2001). Is Unemployment Really Scarring? Effects of Unemployment Experiences on Wages. Economic Journal, 111 (475), F585-606.

AtKin, D. (2016). Endogenous Skill Acquisition and Export Manufacturing in Mexico. American Economic Review, 106 (8), 2046-85.

Banerjee, A. and Mullainathan, S. (2010). The Shape of Temptation: Implications for the Economic Lives of the Poor. NBER Working Papers 15973, National Bureau of Economic Research, Inc.

BARONE, G. and Mocetti, S. (2016). Intergenerational mobility in the very long run: Florence 1427-2011. Temi di discussione (Economic working papers) 1060, Bank of Italy, Economic Research and International Relations Area.

Bauer, A., Garbinti, B. and Georges-Kot, S. (2017). Financial Constraints and SelfEmployment in France, 1945-2014. Tech. rep., INSEE, Banque de France.

Betts, J. R. and MCFARland, L. L. (1995). Safe Port in a Storm: The Impact of Labor Market Conditions on Community College Enrollments. Journal of Human Resources, 30 (4), 741-765.

Black, D. A., McKinnish, T. G. and Sanders, S. G. (2005). Tight Labor Markets and the Demand for Education: Evidence from the Coal Boom and Bust. ILR Review, 59 (1), 3-16.

Black, S. E. and DevereuX, P. J. (2011). Recent Developments in Intergenerational Mobility, Elsevier, Handbook of Labor Economics, vol. 4, chap. 16, pp. 1487-1541.

Bonhomme, S. and Hospido, L. (2017). The cycle of earnings inequality: evidence from spanish social security data. The Economic Journal.

Chabé-Ferret, B. and GobBi, P. (2016). Economic Uncertainty and Fertility Cycles: The case of the post WWII baby boom. Tech. rep., Mimeo, Université Catholique de Louvain. 
Charles, K. K., Hurst, E. and Notowidigdo, M. J. (2015). Housing Booms and Busts, Labor Market Opportunities, and College Attendance. NBER Working Papers 21587, National Bureau of Economic Research, Inc.

Chetty, R., Hendren, N., Kline, P. and Saez, E. (2014). Where is the land of Opportunity? The Geography of Intergenerational Mobility in the United States. The Quarterly Journal of Economics, 129 (4), 1553-1623.

Cockx, B. and GHIRELli, C. (2016). Scars of recessions in a rigid labor market. Labour Economics, 41 (C), 162-176.

CORAK, M. (2013). Income Inequality, Equality of Opportunity, and Intergenerational Mobility. Journal of Economic Perspectives, 27 (3), 79-102.

Cunha, F. and Heckman, J. J. (2008). Formulating, Identifying and Estimating the Technology of Cognitive and Noncognitive Skill Formation. Journal of Human Resources, 43 (4).

—, - and SchennaCh, S. M. (2010). Estimating the Technology of Cognitive and Noncognitive Skill Formation. Econometrica, 78 (3), 883-931.

Dellas, H. and SAKellaris, P. (2003). On the cyclicality of schooling: theory and evidence. Oxford Economic Papers, 55 (1), 148-172.

DEPP (2017). Chapitre 4. les élèves du second degré. Repères et références statistiques.

Esquieu, P. and Poulet-Coulibando, P. (2003). Vers un enseignement secondaire de masse (1985-2001). Données Sociales - La société francaise.

FACK, G. and GRENET, J. (2015). Improving college access and success for low-income students: Evidence from a large need-based grant program. American Economic Journal: Applied Economics, 7 (2), 1-34.

FELER, L. and SEnSES, M. Z. (2017). Trade shocks and the provision of local public goods. American Economic Journal: Economic Policy.

FINDEISEN, S. and S ACHS, D. (2016). Optimal need-based financial aid. Mimeo, University of Mannheim/European University Institute.

Gaini, M., Leduc, A. and Vicard, A. (2013). School as a Shelter? School Leaving-Age and the Business Cycle in France. Annals of Economics and Statistics, (111-112), 251-270. 
Giuliano, P. and Spilimbergo, A. (2014). Growing up in a Recession. Review of Economic Studies, 81 (2), 787-817.

Güell, M., Pellizzari, M., PiCA, G. and Rodrguez Mora, J. V. (2015). Correlating Social Mobility and Economic Outcomes. CEPR Discussion Papers 10496, C.E.P.R. Discussion Papers.

—, Rodrguez Mora, J. V. and Telmer, C. I. (2014). The informational content of surnames, the evolution of intergenerational mobility and assortative mating*. The Review of Economic Studies.

Hagneré, C. and Lefranc, A. (2006). Étendue et conséquences des erreurs de mesure dans les données individuelles d'enquête: une évaluation à partir des données appariées des enquêtes emploi et revenus fiscaux. Economie \& prévision, (3), 131-154.

Hellerstein, J. K. and Morrill, M. S. (2011). Dads and Daughters: The Changing Impact of Fathers on Womens Occupational Choices. Journal of Human Resources, 46 (2), 333-372.

Huttunen, K. and Riukula, K. (2017). Parental job loss and childrens schooling choices. Mimeo, Aalto University.

Inoue, A. and Solon, G. (2010). Two-Sample Instrumental Variables Estimators. The Review of Economics and Statistics, 92 (3), 557-561.

KramarZ, F. and SKAnS, O. N. (2014). When strong ties are strong: Networks and youth labour market entry. Review of Economic Studies, 81 (3), 1164-1200.

LEe, C.-I. and Solon, G. (2009). Trends in Intergenerational Income Mobility. The Review of Economics and Statistics, 91 (4), 766-772.

MAClEAN, J. C. (2013). The health effects of leaving school in a bad economy. Journal of Health Economics, 32 (5), 951-964.

Maier, S. and Vujić, S. (2017). Safe ports for all? schooling responses to jobless times in europe. Mimeo, University of Antwerp.

MÉndeZ, F. and SepúlvedA, F. (2012). The cyclicality of skill acquisition: evidence from panel data. American Economic Journal: Macroeconomics, 4 (3), 128-152. 
Mocetti, S. (2016). Dynasties in professions and the role of rents and regulation: Evidence from italian pharmacies. Journal of Public Economics, 133, 1-10.

Notowidigdo, M. J. (2013). The incidence of local labor demand shocks. Tech. rep., National Bureau of Economic Research.

OECD (2016). PISA 2015. Pisa in focus, OECD Publishing.

Olivetti, C. and PAserman, M. D. (2015). In the name of the son (and the daughter): Intergenerational mobility in the united states, 1850-1940. American Economic Review, 105 (8), $2695-2724$.

Oreopoulos, P., Page, M. and Stevens, A. H. (2008). The Intergenerational Effects of Worker Displacement. Journal of Labor Economics, 26 (3), 455-483.

— and PAGE, M. E. (2006). The Intergenerational Effects of Compulsory Schooling. Journal of Labor Economics, 24 (4), 729-760.

-, von Wachter, T. and Heisz, A. (2012). The Short- and Long-Term Career Effects of Graduating in a Recession. American Economic Journal: Applied Economics, 4 (1), 1-29.

Pekkarinen, T., Uusitalo, R. and Kerr, S. (2009). School tracking and intergenerational income mobility: Evidence from the Finnish comprehensive school reform. Journal of Public Economics, 93 (7-8), 965-973.

RESTUCCIA, D. and URRUTIA, C. (2004). Intergenerational persistence of earnings: The role of early and college education. American Economic Review, 94 (5), 1354-1378.

Rudolf, M. (2015). Les dépenses des familles pour la scolarisation des enfants. Note dinformation DEPP, (29).

SolON, G. (1999). Intergenerational mobility in the labor market. In O. Ashenfelter and D. Card (eds.), Handbook of Labor Economics, vol. 3, Part A, 29, 1st edn., Elsevier, pp. 1761-1800.

Tanaka, T., Camerer, C. F. and Nguyen, Q. (2010). Risk and Time Preferences: Linking Experimental and Household Survey Data from Vietnam. American Economic Review, 100 (1), $557-71$. 


\section{Appendix}

Figure A1 - Achievement Gap across cohorts time

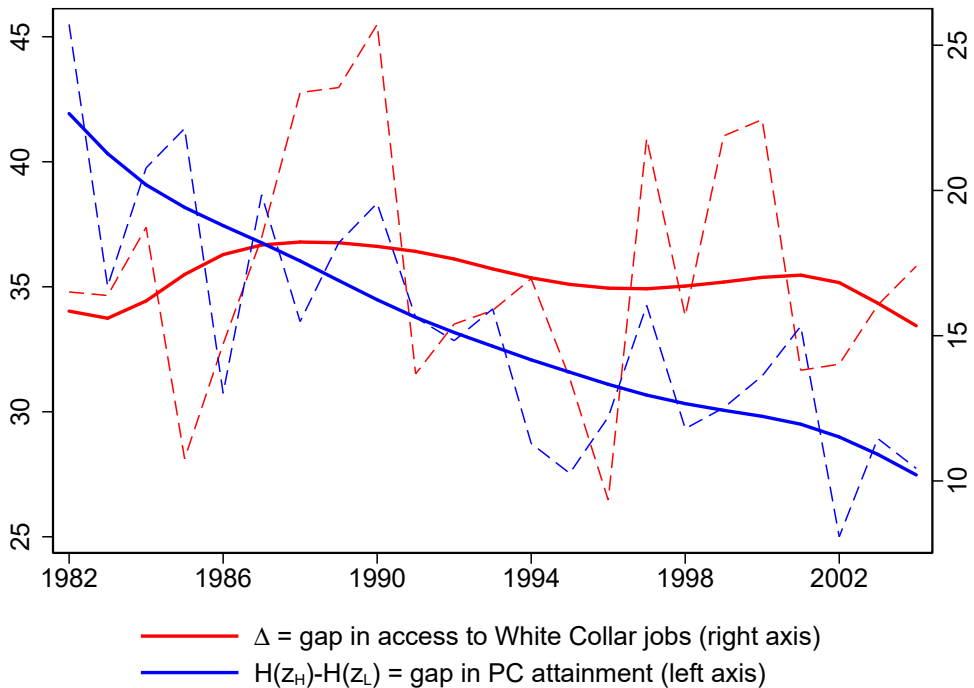

Notes: Thin dash lines represent the cohort specific achievement gap. The thick line corresponds to a smooth series using local weighted regression (lowess) with respect to cohort year.

Table A1 - Length of initial schooling and provincial unemployment rate at 16

(1)

(2)

Length of initial schooling

\begin{tabular}{lcc}
\hline$U_{16, d}^{b p l}$ & 0.0174 & \\
& $(0.0133)$ & \\
$U_{16, d}^{b p l} \times$ WCF & $-0.104^{* * *}$ & $-0.106^{* * *}$ \\
& $(0.0123)$ & $(0.00946)$ \\
\hline Adjusted $R^{2}$ & 0.166 & 0.165 \\
Cohort FE & $\checkmark$ & \\
Prov. $\times$ Parental Occ. FE & $\checkmark$ & $\checkmark$ \\
Prov. $\times$ Cohort FE & & $\checkmark$ \\
Mean Gap in Outcome & 2.3 & 2.3 \\
$\widehat{\beta} \times \frac{\Delta U_{25}^{75}}{\text { gap }}$ & $-12.6 \%$ & $-12.9 \%$ \\
Observations & 195156 & 195138 \\
\hline
\end{tabular}

Notes: WCF stands for white collar father. Robust standard errors in parentheses - clustered at the province $\times$ white collar family level. All regressions control for gender. $* \mathrm{p}<0.1, * * \mathrm{p}<0.05$, *** $\mathrm{p}$ $<0.01$ 
Table A2 - Educational attainment and provincial unemployment rate at 16/18

\begin{tabular}{lcc}
\hline & $\begin{array}{c}(1) \\
\text { PostComp }\end{array}$ & $\begin{array}{c}(2) \\
\text { College }\end{array}$ \\
\hline$U_{16, d}^{b p l} \times \mathrm{WCF}$ & $-0.426^{* * * *}$ & \\
& $(0.143)$ & \\
$U_{18, d}^{b p l} \times \mathrm{WCF}$ & & $-0.415^{* * *}$ \\
& & $(0.150)$ \\
\hline Adjusted $R^{2}$ & 0.053 & 0.158 \\
Prov. $\times$ Parental Occ. FE & $\checkmark$ & $\checkmark$ \\
Prov. $\times$ Cohort FE & $\checkmark$ & $\checkmark$ \\
Dépt by PB trend & $\checkmark$ & $36.7 \mathrm{pp}$ \\
Mean Gap in Outcome & $14.2 \mathrm{pp}$ & $-3.4 \%$ \\
$\widehat{\beta} \times \frac{\Delta U_{25}^{75}}{\text { gap }}$ & $-8.4 \%$ & 198046 \\
Observations & 198046 & \\
\hline
\end{tabular}

Notes: WCF stands for white collar father. Robust standard errors in parentheses - clustered at the province $\times$ white collar family level. All regressions control for gender. $* \mathrm{p}<0.1, * * \mathrm{p}<0.05, * * * \mathrm{p}$ $<0.01$

Figure A2 - Illustration of the Two-Sample 2SLS estimation

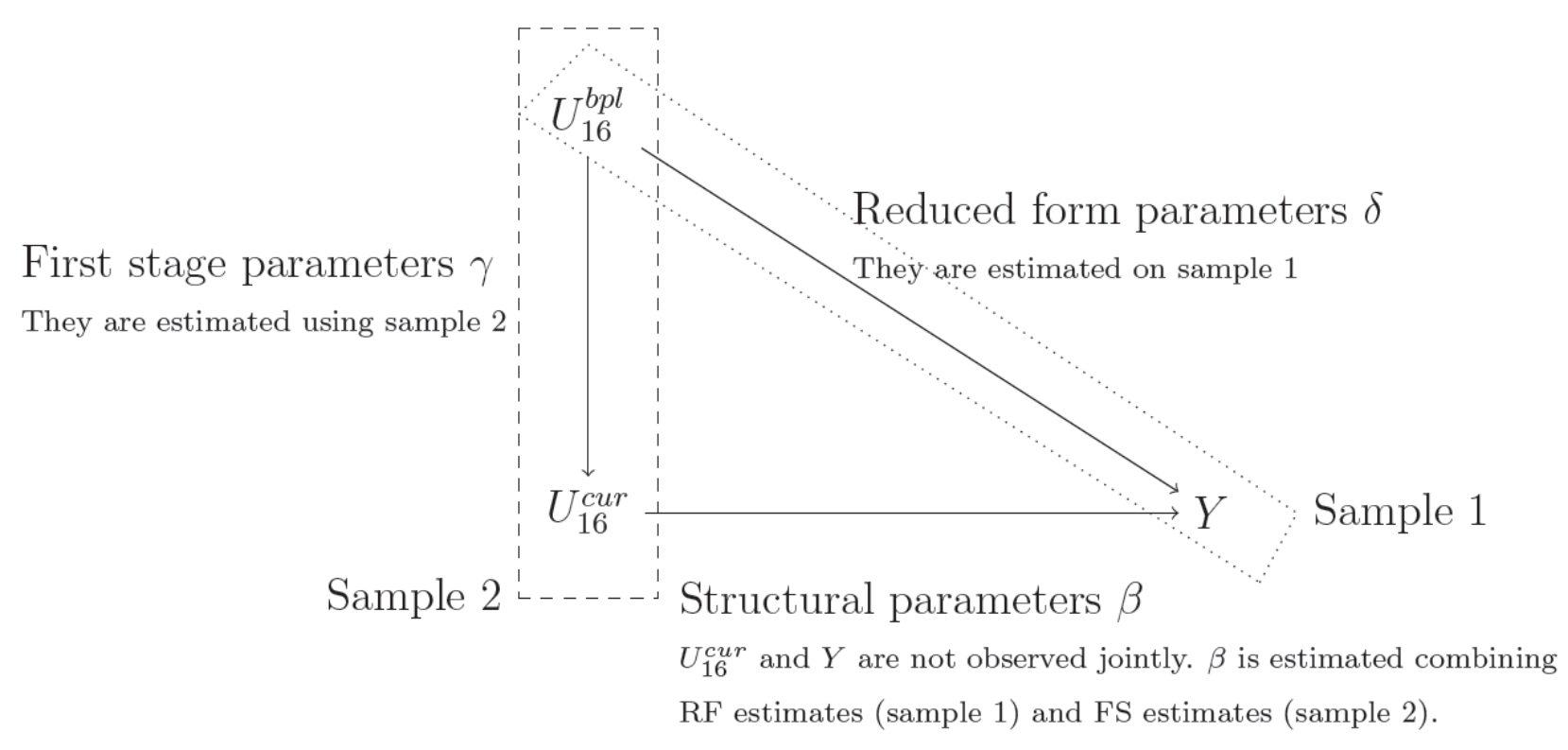

Notes: Sample 1 includes individuals 26 or more at the time of survey - same sample as individuals in school and occupational attainment analysis. Sample 2 includes individuals who are 16 at the time of survey and belong to the same cohorts as sample 1 . We observe birth place for both samples - and therefore deduce the unemployment rate at age 16 in birthplace. However, we observe long-term outcomes (highest degree, occupation) for sample 1 only and we observe current location at age 16 for sample 2 only. 
Table A3 - Occupational status and provincial unemployment rate at 18

\begin{tabular}{lccc}
\hline & $(1)$ & $(2)$ & $(3)$ \\
& White Collar & White Collar & White Collar \\
\hline$U_{18, d}^{b p l}$ & -0.199 & & \\
& $(0.219)$ & & $-0.558^{* * *}$ \\
$U_{18, d}^{b p l} \times$ WCF & $-0.494 * *$ & $-0.651 * * *$ & $(0.178)$ \\
\hline Adjusted $R^{2}$ & $(0.216)$ & $(0.192)$ & 0.130 \\
Prov. $\times$ Parental Occ. FE & 0.123 & 0.130 & $\checkmark$ \\
Cohort FE & $\checkmark$ & $\checkmark$ & $\checkmark$ \\
Cohort $\times$ Prov. FE & $\checkmark$ & $\checkmark$ & $\checkmark$ \\
Age $\times$ Parental Occ. FE & & & \\
Cohort $\times$ Survey FE & & $\checkmark$ & $34.7 \mathrm{pp}$ \\
Mean Gap in Outcome & $34.7 \mathrm{pp}$ & $34.7 \mathrm{pp}$ & $-4.800 \%$ \\
$\widehat{\beta} \times \frac{\Delta U_{25}^{75}}{\text { gap }}$ & $-4.3 \%$ & $-5.600 \%$ & 198092 \\
Observations & 198109 & 198109 & \\
\hline
\end{tabular}

Notes: WCF stands for white collar father. Robust standard errors in parentheses - clustered at the province $\times$ white collar family level. All regressions control for gender. $* \mathrm{p}<0.1, * * \mathrm{p}<0.05, * * * \mathrm{p}$ $<0.01$.

Table A4 - Occupational status and provincial unemployment rate at 16/18

\begin{tabular}{lcc}
\hline & $(1)$ & $(2)$ \\
& White Collar & White Collar \\
\hline$U_{16, d}^{b p l} \times$ WCF & $-0.547^{* * *}$ & \\
& $(0.166)$ & $-0.506^{* * *}$ \\
$U_{18, d}^{b p l} \times$ WCF & & $(0.173)$ \\
\hline Adjusted $R^{2}$ & & 0.130 \\
Prov. $\times$ Parental Occ. FE & 0.130 & $\checkmark$ \\
Cohort $\times$ Prov. FE & $\checkmark$ & $\checkmark$ \\
Age $\times$ Parental Occ. FE & $\checkmark$ & $\checkmark$ \\
Cohort $\times$ Survey FE & $\checkmark$ & $\checkmark$ \\
Dépt by PB trend & $\checkmark$ & $\checkmark$ \\
Mean Gap in Outcome & $\checkmark$ & $34.7 \mathrm{pp}$ \\
$\widehat{\beta} \times \frac{\Delta U_{25}^{75}}{\text { gap }}$ & $34.7 \mathrm{pp}$ & $-4.4 \%$ \\
Observations & $-4.4 \%$ & 198092 \\
\hline
\end{tabular}

Notes: WCF stands for white collar father. Robust standard errors in parentheses - clustered at the province $\times$ white collar family level. All regressions control for gender. $* \mathrm{p}<0.1, * * \mathrm{p}<0.05, * * * \mathrm{p}$ $<0.01$. 
Table A5 - Occupational status and provincial unemployment rate at 16, heterogeneous effects

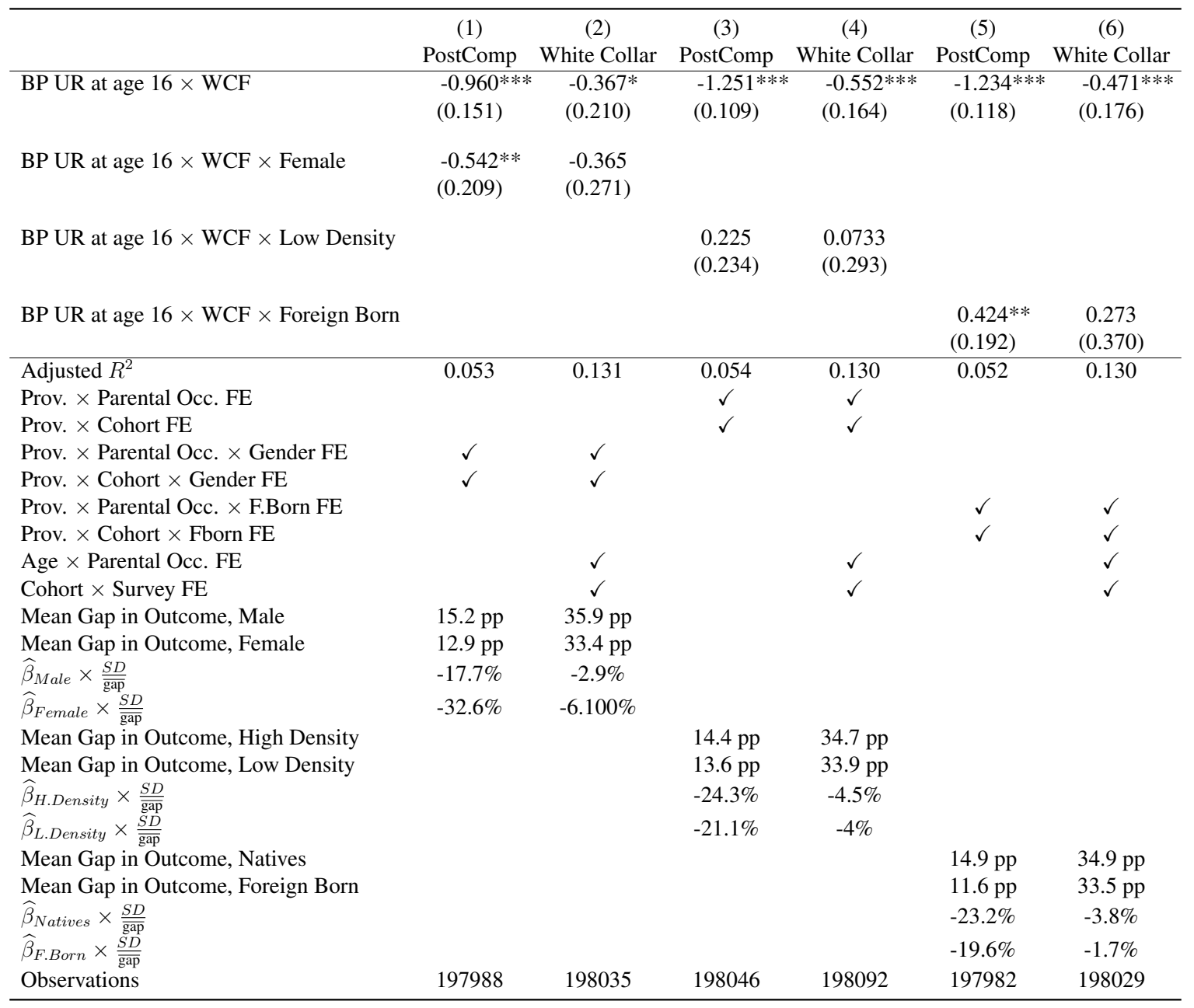

Notes: WCF stands for white collar father. Robust standard errors in parentheses - clustered at the province $\times$ white collar family level. All regressions control for gender. $* \mathrm{p}<0.1, * * \mathrm{p}<0.05, * * * \mathrm{p}<0.01$

Table A6 - Parental Occupation measure and covariates

\begin{tabular}{lccc}
\hline \hline & All & Blue Collar Father & White Collar Father \\
\hline Enrolled in school at age 17 & 85.48 & 80.20 & 94.01 \\
Local Unemp. rate at age 16 (birth) & 8.687 & 8.778 & 8.541 \\
& $(2.249)$ & $(2.262)$ & $(2.219)$ \\
Local Unemp. rate at age 16 (residence) & 8.738 & 8.811 & 8.619 \\
& $(2.221)$ & $(2.237)$ & $(2.192)$ \\
\hline Observations & 14463 & 8936 & 5527 \\
\hline \hline
\end{tabular}

Standard deviation in parenthesis 
ONLINE APPENDIX 
This online appendix includes additional results and robustness checks.

\section{OA1 Robustness checks}

Table OA1 - Occupational mobility: robustness checks with respect to including the "alwaysunemployed" and self-employed

\begin{tabular}{lcccc}
\hline & \multicolumn{3}{c}{ Including always unemployed } & + Self-employed \\
& $(1)$ & $(2)$ & $(3)$ & $(4)$ \\
& White Collar & White Collar & White Collar & a3 \\
\hline$U_{16, d}^{b p l}$ & -0.125 & -0.0746 & & \\
& $(0.218)$ & $(0.214)$ & & \\
$U_{16, d}^{b p l} \times$ WCF & & & & \\
& $-0.444^{* *}$ & $-0.516^{* *}$ & $-0.476^{* * *}$ & $-0.421^{* * *}$ \\
\hline Adjusted $R^{2}$ & $(0.199)$ & $(0.207)$ & $(0.146)$ & $(0.135)$ \\
Prov. $\times$ Parental Occ. FE & 0.121 & 0.129 & 0.129 & 0.120 \\
Cohort FE & $\checkmark$ & $\checkmark$ & $\checkmark$ & $\checkmark$ \\
Cohort $\times$ Prov. FE & $\checkmark$ & $\checkmark$ & & \\
Age $\times$ Parental Occ. FE & & & $\checkmark$ & $\checkmark$ \\
Cohort $\times$ Survey FE & & $\checkmark$ & $\checkmark$ & $\checkmark$ \\
Mean Gap in Outcome & $34.4 \mathrm{pp}$ & $34.4 \mathrm{pp}$ & $34.4 \mathrm{pp}$ & $33.2 \mathrm{pp}$ \\
$\widehat{\beta} \times \frac{\Delta U_{5}^{75}}{\text { gap }}$ & $-3.9 \%$ & $-4.5 \%$ & $-4.2 \%$ & $-3.8 \%$ \\
Observations & 199606 & 199606 & 199590 & 207802 \\
\hline
\end{tabular}

Notes: WCF stands for white collar father. Robust standard errors in parentheses - clustered at the province $\times$ white collar family level. All regressions control for gender. $* \mathrm{p}<0.1, * * \mathrm{p}<0.05$, $* * * \mathrm{p}<0.01$

Table OA2 - Log wage and provincial unemployment rate at 16

\begin{tabular}{lccc}
\hline & $(1)$ & $(2)$ & $(3)$ \\
& $\ln ($ wage $)$ & $\ln ($ wage $)$ & $\ln ($ wage $)$ \\
\hline$U_{16, d}^{b p l}$ & 0.00146 & 0.00284 & \\
& $(0.00220)$ & $(0.00207)$ & \\
$U_{16, d}^{b p l} \times$ WCF & & & \\
& $-0.0149^{* * *}$ & $-0.0125^{* * *}$ & $-0.0112^{* * * *}$ \\
\hline Adjusted $R^{2}$ & $(0.00264)$ & $(0.00244)$ & $(0.00166)$ \\
Prov. $\times$ Parental Occ. FE & 0.126 & 0.254 & 0.254 \\
Cohort FE & $\checkmark$ & $\checkmark$ & $\checkmark$ \\
Cohort $\times$ Prov. FE & $\checkmark$ & $\checkmark$ & $\checkmark$ \\
Age $\times$ Parental Occ. FE & & $\checkmark$ & $\checkmark$ \\
Cohort $\times$ Survey FE & & $\checkmark$ & .23 \\
Mean Gap in Outcome & .23 & $-15.7 \%$ & $-14.1 \%$ \\
$\widehat{\beta} \times \frac{\Delta U_{25}^{75}}{\text { gap }}$ & $-18.8 \%$ & 176677 & 176656 \\
Observations & 176677 & .767 \\
\hline
\end{tabular}

Notes: WCF stands for white collar father. Robust standard errors in parentheses - clustered at the province $\times$ white collar family level. All regressions control for gender. $* \mathrm{p}<0.1, * * \mathrm{p}<0.05$, *** $\mathrm{p}<0.01$. The wage is defined as monthly earnings. For individuals with more than one valid observations for wage, we compute the simple average before taking the log. 